\title{
The Impact of Collections Strategy on the Profitability of Unsecured Bank Microloans
}

\section{Amos Kahn}

A research project submitted to the Gordon Institute of Business Science, University of Pretoria, in partial fulfilment of the requirements for the degree of Master of Business Administration. 


\section{ABSTRACT}

There has been little empirical work on how collections strategy can be used to maximise profits. The aim of this research was to investigate the impact that one particular collections strategy, called behaviour based collections, had on the costs, revenues and eventual collections outcome of defaulted microloans. This is one of the few studies on the collections function, and perhaps the first to investigate this aspect of collections strategy.

Microloan books from different business units were analysed and compared. One business used a behaviour based strategy to collect on arrears, in which a client was expected to establish regular payment behaviour before repaying the arrears amount. The other used an arrears based strategy, where the client was expected to repay missed instalments immediately. Measurements of cash flow, eventual collections outcome, costs and change in credit risk were taken from each sample and tested using Mann-Whitney $U$ tests and chi-square tests.

The results show that the eventual collections outcome (whether the defaulted loan is rehabilitated or written off) does not vary according to collections strategy. For both strategies, as credit risk worsens, there is a decrease in revenue received; as credit risk improves, revenue received rises. In contrast to industry best practice, the research finds that behaviour based collections results in $3.37 \%$ more revenue when the loan is rehabilitated, and a $4.54 \%$ reduction in losses when the loan is written off. The research also finds that the cost of using a behaviour based collections strategy is lower than using an arrears based strategy. These results suggest that the collections industry can realise significant gains from the application of behaviour based collections. 


\section{DECLARATION}

I declare that this research project is my own work. It is submitted in partial fulfilment of the requirements for the degree of Master of Business Administration at the Gordon Institute of Business Science, University of Pretoria. It has not been submitted before for any degree or examination in any other University.

\section{Amos Kahn}

November 2006 


\section{ACKNOWLEDGEMENTS}

I would like to express my gratitude for the immense patience and support of my wife Angela over the last two years. Not only did she agree to marry me, but she didn't immediately divorce me when she realised what she was taking on.

I'd also like to thank my supervisor Mike Ward for deciphering my convoluted way of expressing myself and keeping me on track. It was a pleasure to work with him.

Finally, I owe a debt of gratitude to my employer for giving me the time, space and resources to complete this research. 


\section{Table of Contents}

ABSTRACT

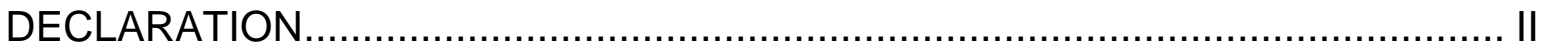

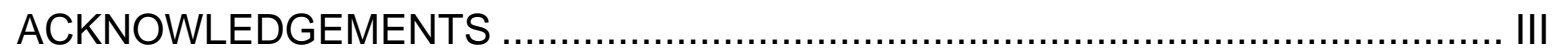

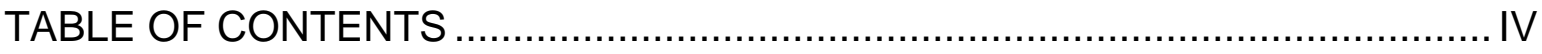

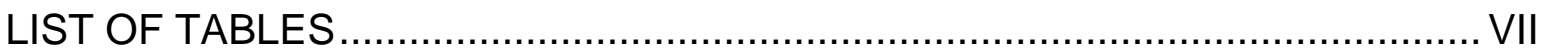

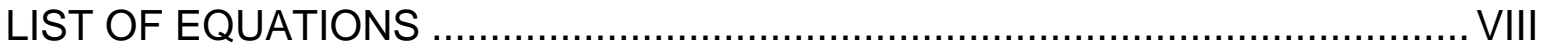

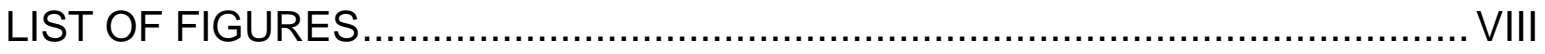

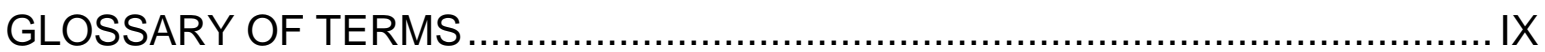

CHAPTER 1: INTRODUCTION TO THE RESEARCH PROBLEM ..................... 1

CHAPTER 2: THEORY AND LITERATURE REVIEW .................................... 6

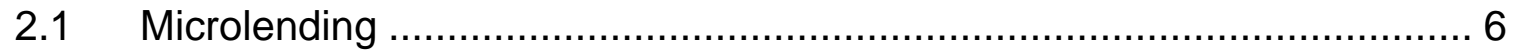

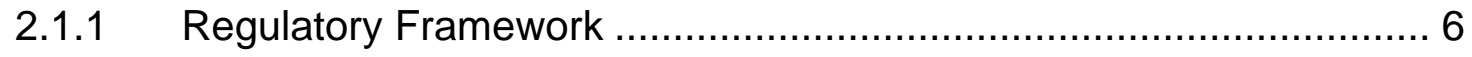

2.1.2 Demand for Credit ......................................................................... 7

2.1.3 The Growth of the Microlending Sector ...................................... 8

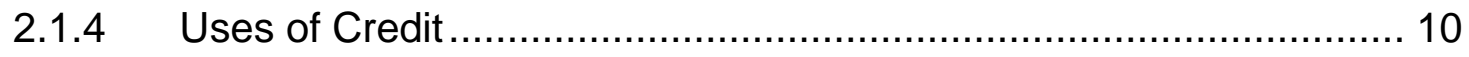

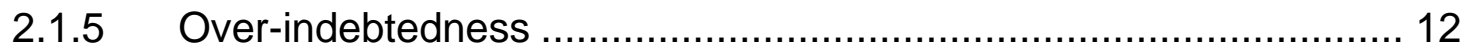

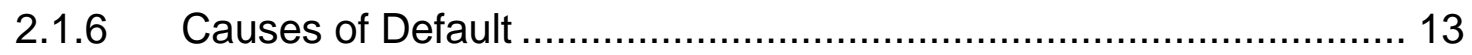

2.2 Profit and Loss: The Dynamics of Lending ..................................... 13

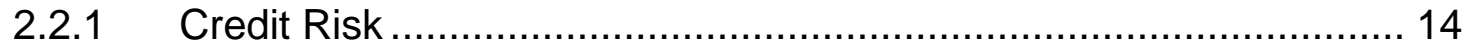

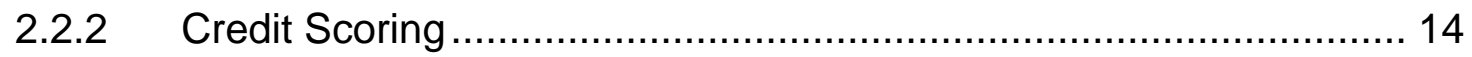

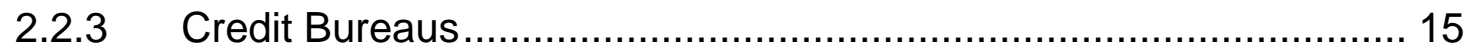

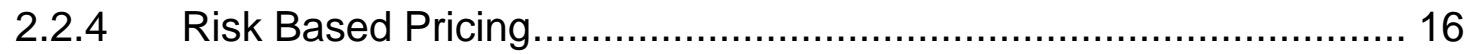




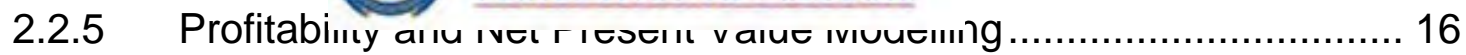

2.2.6 Lending to the Low Income Market.................................. 17

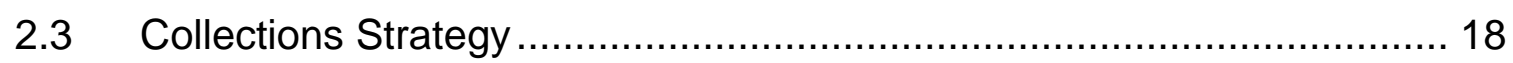

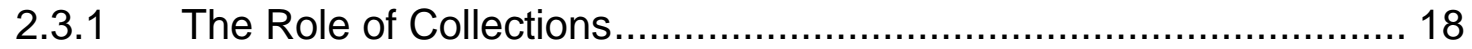

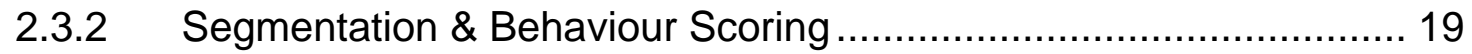

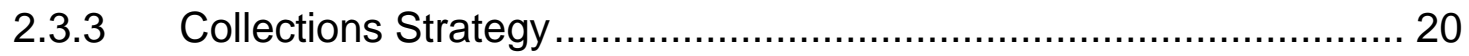

2.3.4 Arrears Based Collections - The Traditional Role ....................... 21

2.3.5 Behaviour Based Collections - An Alternative Approach ............... 21

2.3.6 Collections and Profitability .......................................... 23

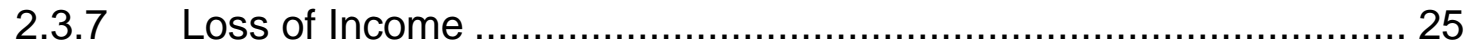

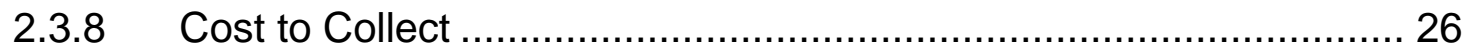

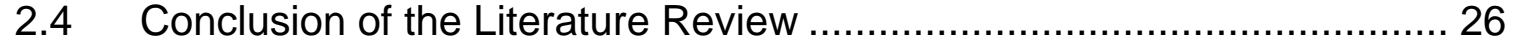

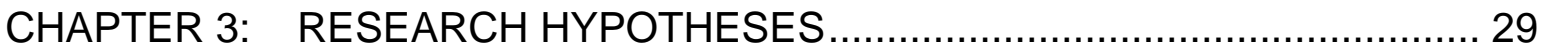

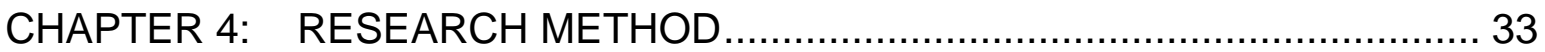

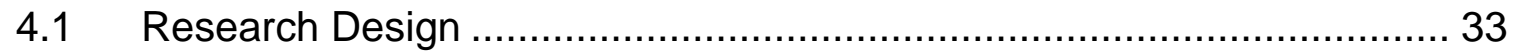

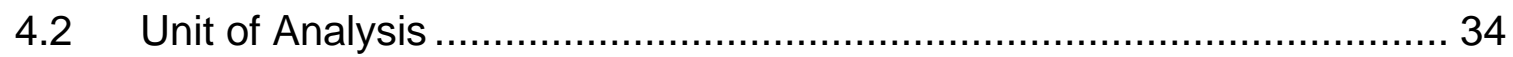

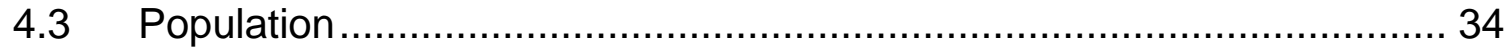

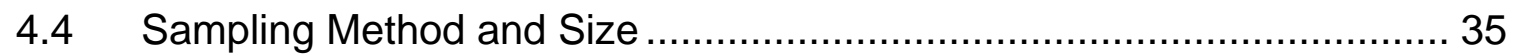

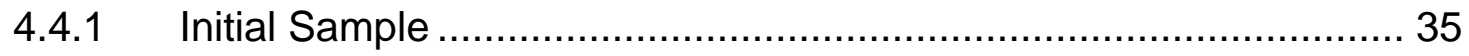

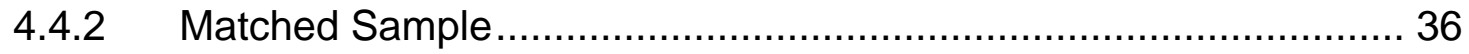

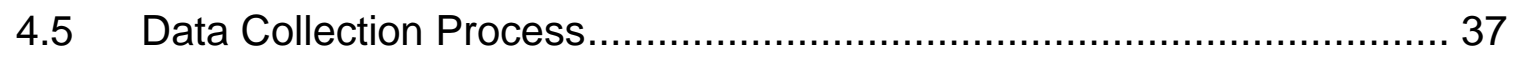

4.5.1 Stage 1: Account Identification ....................................... 37

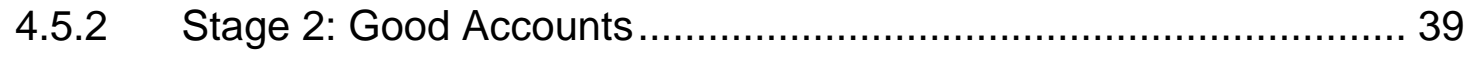

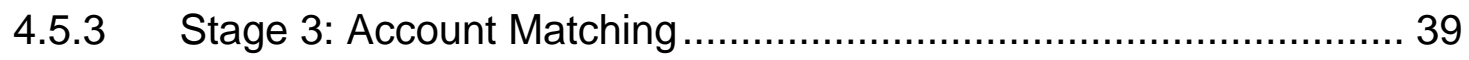




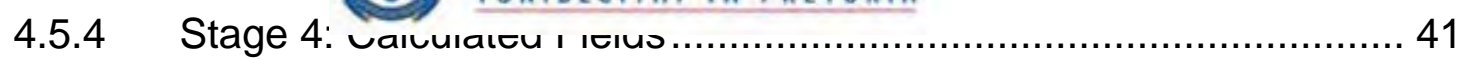

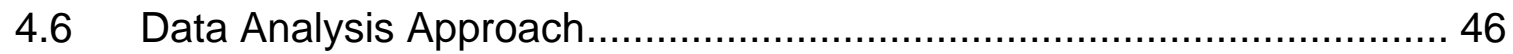

4.6.1 Cash Flow Margin ................................................................... 46

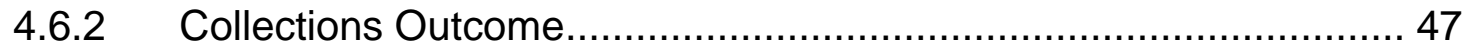

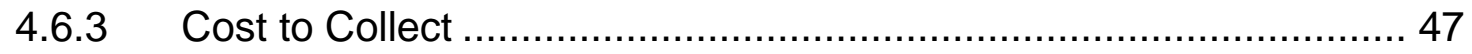

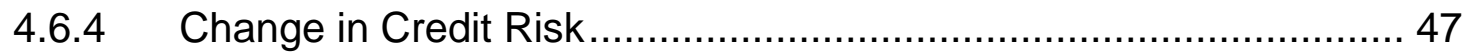

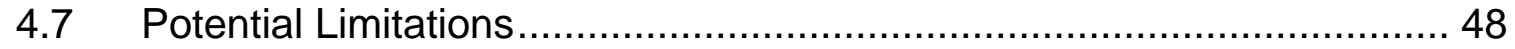

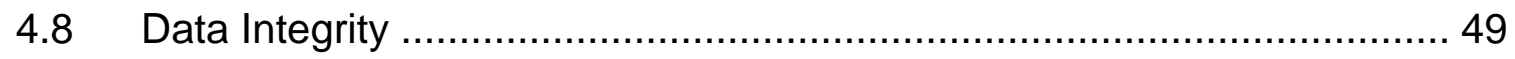

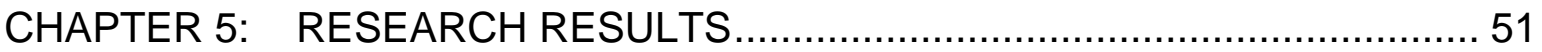

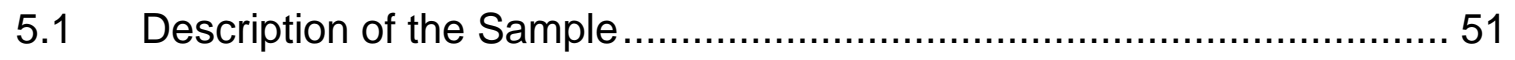

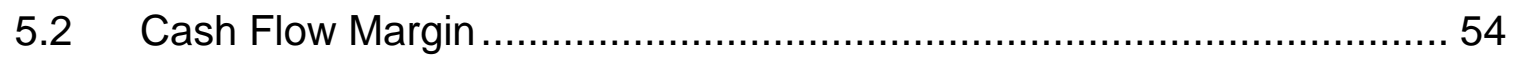

5.2.1 Mean Cash Flow Margin ........................................................ 54

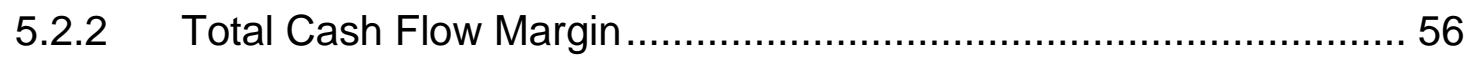

5.3 Collections Outcome

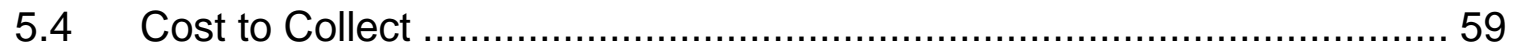

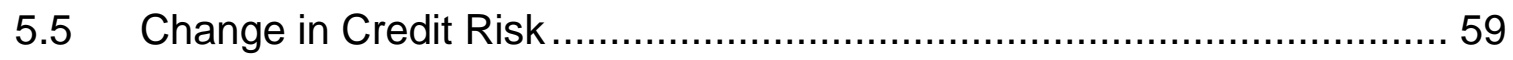

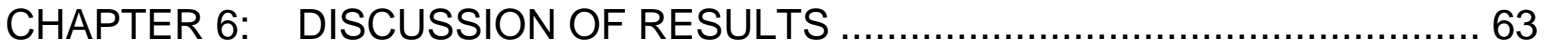

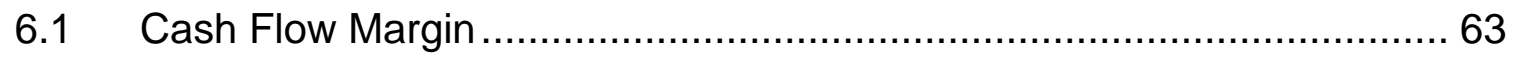

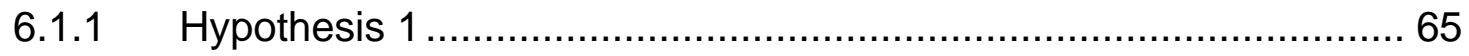

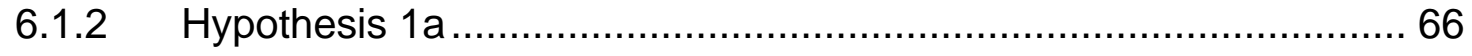

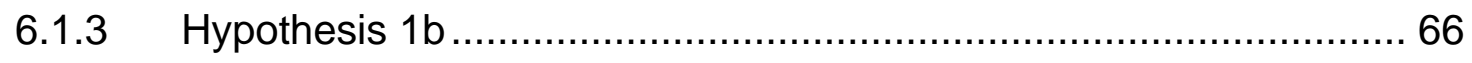

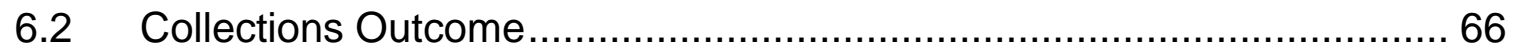

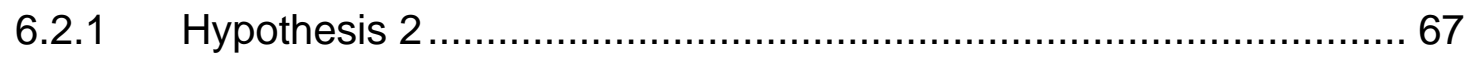

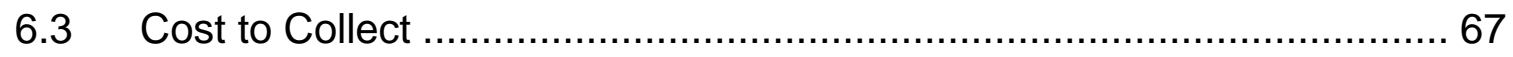




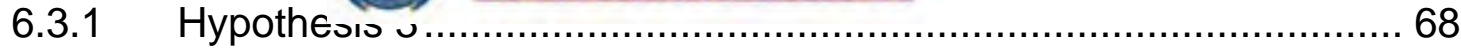

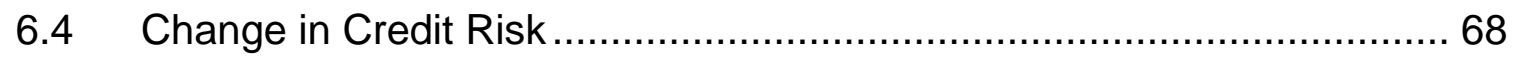

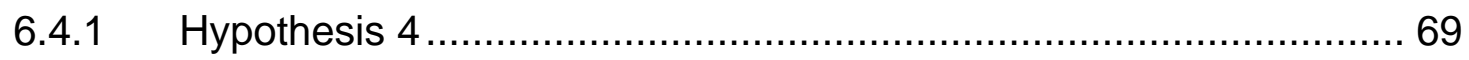

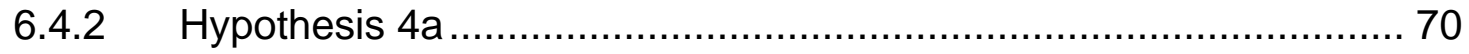

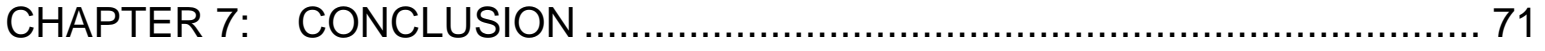

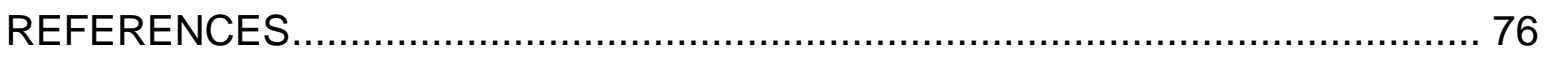

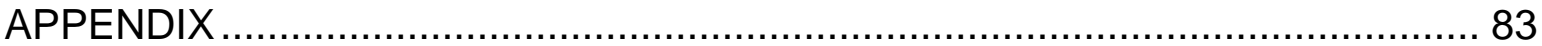

\section{List of Tables}

Table 4-1 Example Loan Metrics ….................................................. 42

Table 5-1 Default Accounts Before and After Matching …........................... 52

Table 5-2 Good Accounts Before and After Matching.................................. 53

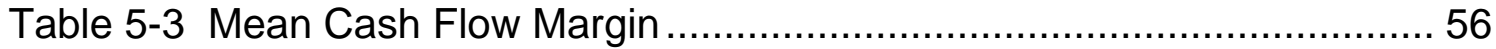

Table 5-4 Total Cash Flow Margin per Book............................................ 57

Table 5-5 Chi Square Test of Collections Outcome vs. Collections Strategy.. 58

Table 5-6 Right Party Contacts (RPC) per Collections Strategy .................... 59

Table 5-7 Chi Square Test of Change in Credit Risk per Loan Book .............. 60

Table 5-8 Chi Square Test - Credit Risk vs Cash Flow Margin (Book 1) ........ 61

Table 5-9 Chi Square Test - Credit Risk vs. Cash Flow Margin (Book 2) ........ 62 


\section{List of Equations}

Equation 1: Actual Profit Margin.................................................. 17

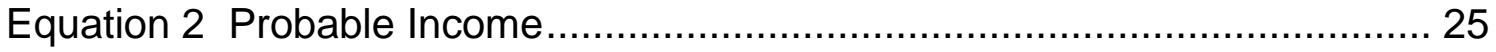

Equation 3 Cash Flow Margin .................................................. 26

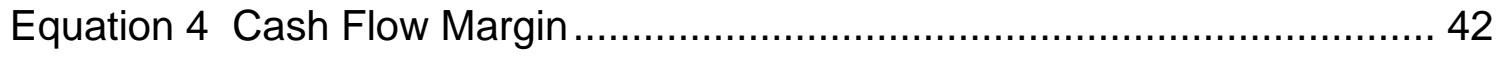

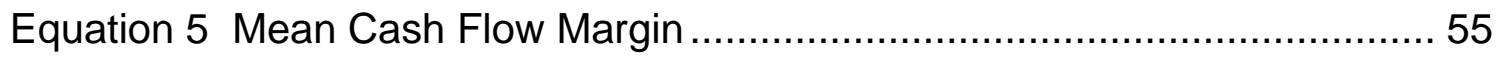

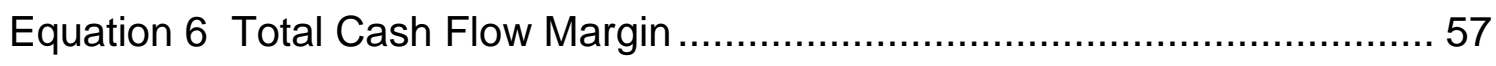

\section{List of Figures}

Figure 1 Annual Microloan Disbursements (Formal Sector) ..................... 9

Figure 2 Number of Accounts and Loan Book Size ............................. 10

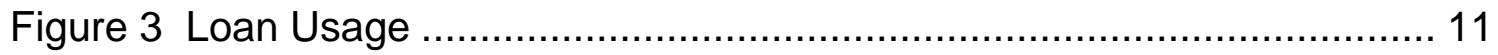

Figure 4 Cash Flow Margin for Defaulted Accounts ............................. 54

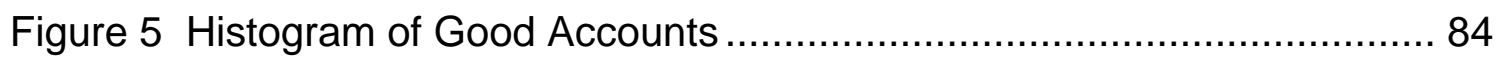

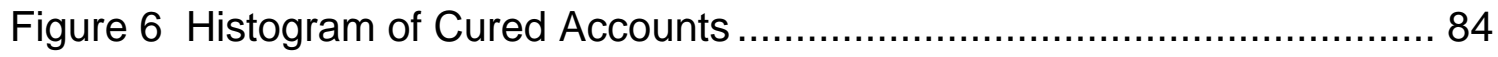

Figure 7 Histogram of Written Off Accounts..................................... 85 


\section{Glossary of Terms}

Arrears

Arrears bucket

Arrears based collections

Behaviour based collections

Credit policy

Cure

Default
The status of the loan when the client is behind schedule with his payments. It is measured in either rand value or time period. For example, a client may be 2 months in arrears after missing two payments.

A set of accounts grouped by arrears status. For example, all accounts that are 2 months in arrears could be grouped together.

A collections strategy that focuses on reducing the arrears status of the client. The desired client behaviour is immediate repayment of all arrears.

A collections strategy that focuses on improving the payment profile of the account. The desired client behaviour is regular payment of future instalments.

The business rules around lending as well as the structure of the loan

When a loan enters default but the client repays any missed instalments and penalty interest either immediately or at the end of the term.

For the purpose of this research, default is defined as occurring when the client is two months in arrears. 
Disbursement

Recency based collections Same as behaviour based collections.

Paid up

Payment profile

Provisioning

Recoveries

Rehabilitate

Term

Write Off initiated, the loan is considered written off. expected future losses on bad debt. instalment but paid the previous two.

\section{initiated, the loan is considered witten off.} immediately or at the end of the term.

The period of the loan

When normal collections have been exhausted the legal process is initiated to recover any outstanding debt. For this research, if the recovery process is

A financial process whereby money is set aside (as a loss item on the income statement) to provide for

payment behaviour of a loan account. For example, 111 means the client has paid her last three instalments, while 110 means she missed her last

When a loan enters default but the client repays any missed instalments and penalty interest either

When a defaulted loan cannot be rehabilitated and the client is IInwillinn or unahle tn nav hic deht the 


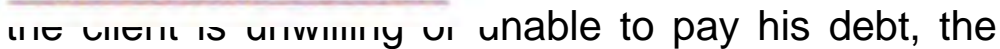
loan may be written off and a legal process initiated to recover the monies owed. This is usually done when the cost of collections outweighs the likely revenue received from the client. 


\section{Chapter 1: Introduction to the Research Problem}

South Africans are borrowing money at an ever-increasing rate. At the end of 2006, after three years of successive growth, household debt as a proportion of income stood at its highest ever level, 65.6\% (South African Reserve Bank, 2006). This growth has been attributed to a benign macro-economic environment but has begun to give economists cause for concern and is cited as a factor in recent interest rate hikes (Bloomberg, 2006; Seria, 2006).

At the same time, the financial sector charter (FSC) has served to focus banks' attention on delivering to the poor (Planting, 2004). The profitability of market pioneers like African Bank, Standard Bank and Capitec have helped institutions realise that providing financial services to this market can be an attractive business proposition (Gunnion, 2006). Significant progress has been made, particularly in the areas of transactional banking and microloans (Porteous in Planting, 2004).

This deepening of financial markets has taken place against a backdrop of increased liberalisation in the sector since 1990. The Exemption to the Usury Act in 1992 effectively established the micro-finance industry by removing interest rate ceilings on loans with a value below R6,000 and a repayment term of less than 36 months. Another exemption followed in 1999, in response to demand for larger loans, increasing the loan ceiling from R6,000 to R10,000 (Daniels, 2001a; Daniels, 2001b). This liberalisation led to strong growth in the microfinance market, largely in unsecured debt (Microfinance Regulatory Council, 2006; Hawkins, 2003; Schoombee, 2004). The Microfinance Regulatory Council, a body set up to regulate the microfinance industry, reports that in the 12 months ending 


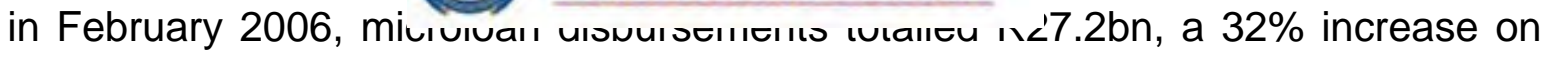
the preceding 12 months (Microfinance Regulatory Council, 2006).

The banks that are doing well in the area of microlending make the most of information-based credit management (Schoombee, 2004). Most use application scorecards as the basis for decision making, as well as making use of credit bureau data for identifying clients to solicit with offers of new loans. Both these aspects of doing business are threatened by pending legislation in the form of the National Credit Act which comes into effect in June 2007. On the marketing side, the Act prevents querying credit bureaus without a client's (or potential client's) explicit permission. In terms of application processing, the quality of data available from credit bureaus may be negatively impacted since the Act also places restrictions on the nature and duration of data stored on members of the public (National Credit Act, 2005).

Ironically, these impending constraints have led to an increase in supply of credit available before the new laws come into effect. Many new businesses are entering the market, and existing businesses are pushing hard to grow market share before it becomes more difficult to identify high risk customers and harder to market to low risk ones (Gilmour, 2006). This may lead to an increase in the risk profile of a bank's loan book, as more customers are likely to become over-indebted. In addition, the market for low risk clients is becoming more competitive and more loans are being granted to high risk customers (African Bank Trading Update, 2006).

There is also a tendency towards over-indebtedness in the target market and most 


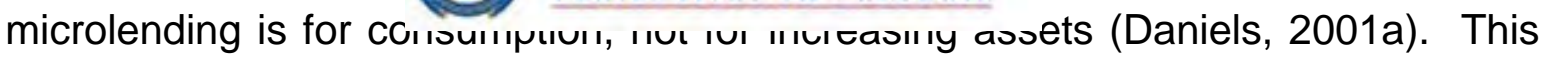
kind of lending therefore does not increase a household's future ability to pay back the loan.

The above factors increase the role of collections in the bank as increasing number of high risk clients are being booked. While loans may be priced for risk, with the expectation of certain levels of bad debt, the collections department still plays an important role in managing risk on the debt portfolio (Bailey, 2002).

When a client falls into arrears on an instalment loan, the creditor faces a problem - how to maximise revenue while minimising costs. At this stage, the client relationship is usually managed by the collections department of the firm. This department is responsible for collecting payments from clients who pay late or do not pay at all (Spinks \& Wells, 1997). The department needs to assess the most cost effective way of doing this (Rial, 2005).

Collections is typically seen as a cost centre for managing risk, with a focus purely on retrieving outstanding amounts as fast as possible (Bailey, 2002; Miller, 2002). This approach has two shortcomings. Firstly, a delay in cash flow may be more profitable if it earns interest above the cost of capital. Secondly, the client may not be able to pay the arrears amount, and as Bailey (2002) describes, pressurising the client to "catch up" strains the relationship between the client and the bank.

An option that needs to be considered is using collections strategy to actively increase the profitability of clients in default. The most profitable clients could be those that pay irregularly, but do pay eventually, provided interest is charged on any missed payments. In fact, businesses like Capital One in the United States, a 


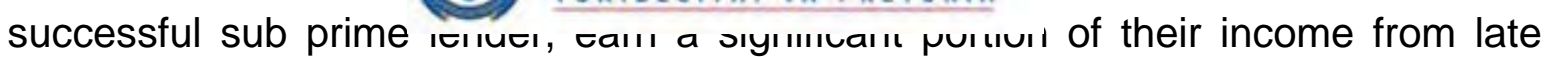
fees and penalty interest (BusinessWeek, 2006).

The aim of this research is to examine this possibility in the light of two different collections strategies. The first strategy, referred to as behaviour based collections in this text, but also called recency based collections, is one that focuses on a client's payment behaviour. If a client falls into arrears on the loan (i.e. misses some payments and falls behind in their repayment schedule), the goal of this strategy is to rehabilitate the client only so far as their payment behaviour is concerned. This means ensuring regular payments from the client in future, and recovering any previously missed payments only when the client is able to pay - if necessary at the end of the term of the loan. The second and more common strategy, known as arrears based collections, is one that focuses on recovering previously missed payments as soon as possible as well as securing the next payment. The desired client behaviour is immediate repayment of the full arrears amount.

This study seeks to discover the circumstances under which the different approaches positively impact loan cash flow margin. This is a measure of how much revenue is received on a loan compared to how much was expected. The study also examines the relative costs associated with each collections strategy.

This research appears to be the first comparison of different collections strategies and the impact these have on revenue. Previous empirical studies focus on the recovery rate of defaulted loans but neglect to consider the role of the collections function. There is little academic literature on the payment behaviour of microloan 


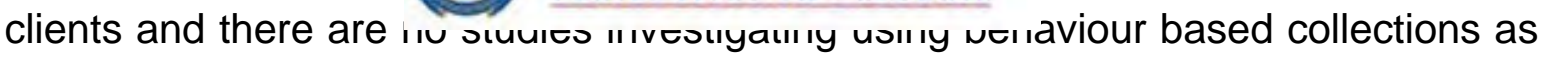
a way of increasing the likelihood of payment, reducing costs, or increasing future cash flows.

The remainder of this research report is structured as follows: Chapter 2 consists of a literature review that covers the theory base, Chapter 3 lays out the research hypotheses. The research method employed is described in Chapter 4 while Chapter 5 presents the results of the research. These results are discussed in Chapter 6, and Chapter 7 contains the conclusion. 


\section{Chapter 2: Theory and Literature Review}

The literature review starts by discussing microlending. It covers both supply and demand aspects as well as pertinent legislation. There are many statistics available on these topics but a limited number of empirical studies. Attention is then turned to the dynamics of lending, and topics around risk measurement and profitability are discussed. The next discussion area is that of collections strategy. There is a shortage of empirical research in this area, so much of the discussion is around best practice and methodologies advocated (but not proved) by industry specialists. The theory base is then discussed and a new metric, the cash flow margin, is introduced. The chapter concludes by highlighting how this research will contribute to closing the gaps illustrated by the literature review.

\section{$2.1 \quad$ Microlending}

\subsubsection{Regulatory Framework}

Since 1992, microlending has been governed by two Exemption Notices to the Usury Act. These exempt loans below R10,000 with a term less than 36 months from the interest rate ceilings set by the Usury Act. They also legislated the creation of the Microfinance Regulatory Council (MFRC), an institution mandated to ensure the sustainability of the sector as well as provide consumer protection (Schoombee, 2004).

In June 2007, a new act will come into effect to unify all credit activity in South Africa. The National Credit Act (NCA) replaces the Usury Act (and its Exemption Notices) as well as the Credit Agreements Act which governed instalment sales. 


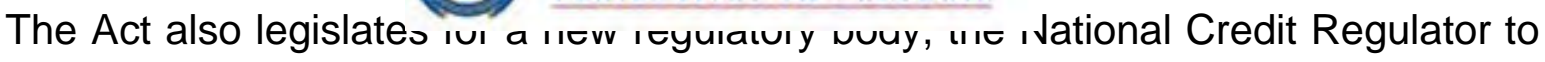
enforce the act (this body replaces the MFRC). The NCA defines maximum interest rates and charges that can be levied on loans as well as being the first legislation to regulate the credit bureaus. It also mandates against reckless lending, defined as having occurred when a loan was granted where the grantor could reasonably have ascertained that the debtor would have been unable to afford the loan repayments. It places the onus on credit providers to prevent reckless lending, and holds them accountable should this happen (National Credit Act, 2005).

\subsubsection{Demand for Credit}

Rust (2002) states that there is huge demand for credit in the low to moderate income bands, generally accepted as individuals with incomes below R7,500 per month (Pearson \& Greef, 2006). Rutherford (2005) describes some of the difficulties the poor face in saving money. These include high transaction costs relative to amount saved, lack of access to savings instruments, risk of theft, and external demands on any money left over. These difficulties help explain the popularity and demand for credit in the low income market.

Consumption theory suggests that life cycle events, emergencies, business opportunities and consumption needs result in required expenditure exceeding current income. This requires either saving up, where a lump sum has already been put aside, or saving down, where a loan is taken and paid back over time (Rutherford, 2005). A 2003 report to the MFRC (Ebony Consulting International, 2003) describes the fact that poor people tend to borrow more often than save as 


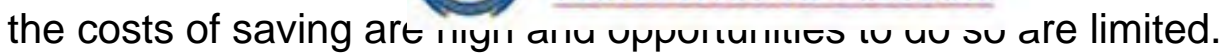

Daniels (2001a) finds that demand for credit from middle and low income groups is highly inelastic. This inelasticity may be explained by lack of competition from formal lenders in this sector, and the high demand for cash due to low cash flow levels.

\subsubsection{The Growth of the Microlending Sector}

The changes to the regulatory environment described in section 2.1.1 above combined with the significant latent demand described in section 2.1.2 resulted in microlending becoming a significant part of the South African economy within a relatively short period of time (Daniels, 2004). This growth is illustrated in Figure 1. By the year 2000 , microfinance accounted for $2 \%$ of the financial services sector (Daniels, 2001b). While this may seem insignificant, for a new industry to grow so much in ten years is quite remarkable. It's also important to realise that the relatively small size of loans disbursed means that a large number of people are served by this industry, so its influence is quite significant (Coetzee, Druschel, Cook, Brislin, Meagher \& Pearson, 2005). Figure 2 illustrates this, though note that the number of accounts does not equate to the number of people served, as some individuals have more than one loan. Coetzee et al (2005) estimate that the actual number of clients is approximately half the number of accounts.

The initial entrants into this sector were non-bank lenders including large retailers and small microlenders, though the large banks have now followed suit. There are also three new banks - African Bank, Teba Bank, and Capitec - catering exclusively to this market. By $1999 / 2000,38 \%$ of the value of loan disbursements 
were from banks, with aı aveıayc aııuиı и п , vuv (vaniels, 2001b).

Figure 1 Annual Microloan Disbursements (Formal Sector)

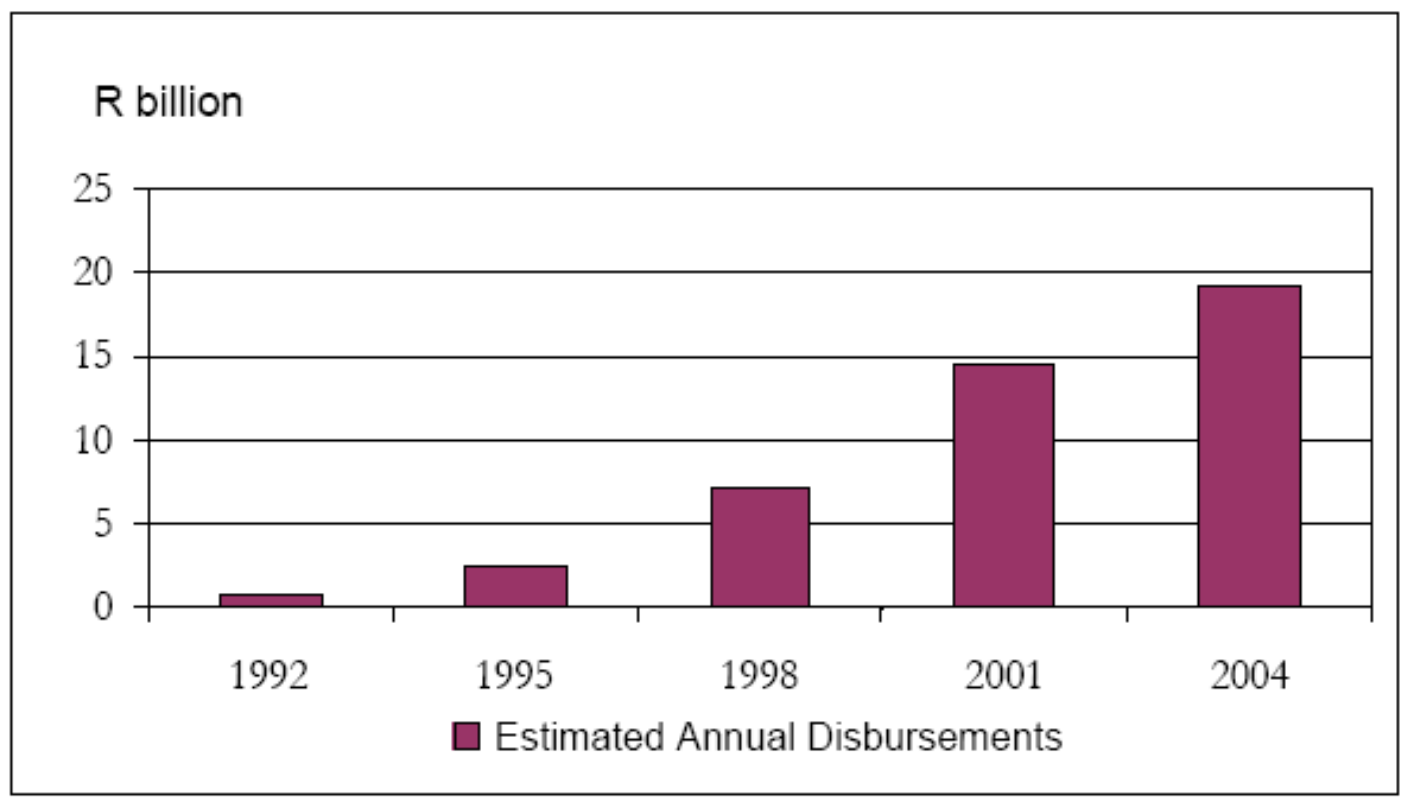

Source: MFRC in Coetzee et al (2005)

Political pressure in the form of the financial sector charter also helped drive this growth. In providing financial services to the poor, the emphasis of most banks has been on opening up access to loans. These include mortgages, credit cards, overdrafts, personal loans, instalment sales, retail credit and microloans (Hawkins, 2003). 


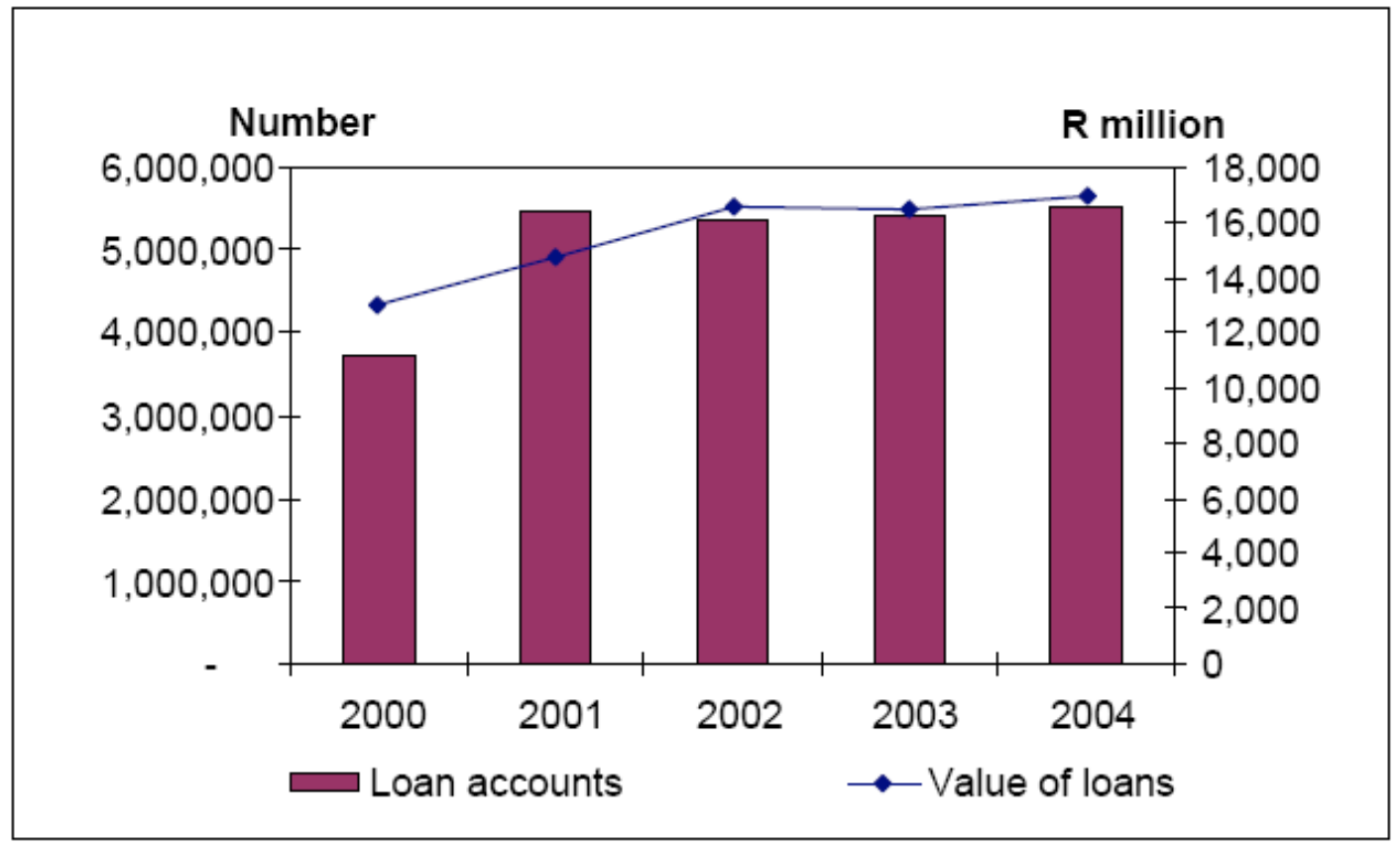

Source: MFRC in Coetzee et al (2005)

\subsubsection{Uses of Credit}

The FinScope 2005 survey on financial services finds that just $6 \%$ of lending is to start a business while the rest is used for consumption and housing (Munshi, 2005). While this survey has the limitation that $48 \%$ of respondents did not elaborate on the reason for the loan, the results are similar to those of a report presented to the MFRC by Ebony Consulting International (2003). This report provides detailed analysis of the current use of microloans and categorises them into three groups, namely life cycle needs (such as education, weddings and funerals), family emergency needs, and business development needs. The report makes the observation that due to the many different uses for money and issues around data collection, it is only possible to provide indicative figures, as the stated 
use of the loan may ıи ııамı uг auıua usc. ı ıvvever, the results match the

Finscope 2005 survey and find that $25-35 \%$ of all borrowing is for consumption purposes while only $2-4 \%$ is for business development. The remainder is split between housing, education and other unspecified reasons. These findings are illustrated in Figure 3.

The fact that there is little borrowing for microenterprise is a concern as it is this form of borrowing that is expected to have the biggest impact on improving social welfare. Consumption borrowing does not increase the future repayment capacity of the household and can rapidly lead to households becoming over-indebted (Ebony Consulting International, 2003).

\section{Figure 3 Loan Usage}

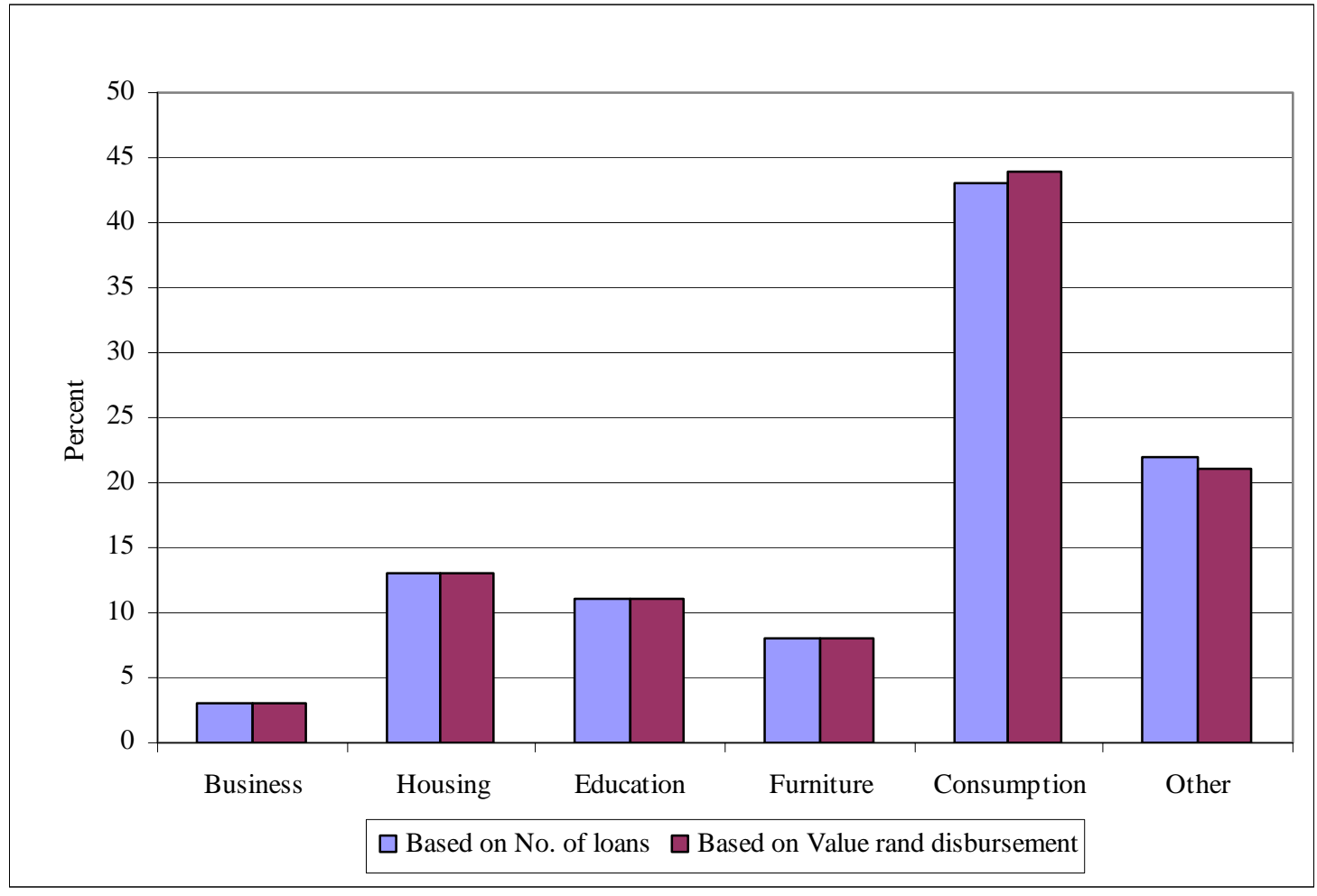

Source: MFRC in Ebony Consulting International (2003) 


\subsubsection{Over-indebtedrico}

Much of the information on over-indebtedness is anecdotal in nature, and there are few studies that take an empirical approach to the topic. A study by Marsh \& Saran (1999) finds that unscrupulous behaviour of microlenders, combined with the desperate need for finance is a contributing factor to over-indebtedness. Pearson \& Greef (2006) analyse data from a credit bureau and discover that over $50 \%$ of the holders of housing microloans can be considered to be over-indebted as their instalments were greater than $20 \%$ of their income. Hawkins (2003) shows that the debt to income ratio in South Africa is unusually high at the lowest income levels.

These findings are contradicted in Daniels (2001a) where analysis of changes in household indebtedness and cash flow between 1995 and 1999 is undertaken. That study finds that levels of debt in the lowest income bands are actually quite low, with only a slight increase at the lowest income levels. Daniels (2001a) comments that this result is surprising given anecdotal evidence of high moneylending activity and suggests that it could be a result of the data aggregation hiding outliers, or due to low levels of access to the formal banking sector. In a later article, Daniels (2004) finds that the rapid growth of the microcredit industry led to greater access to credit for lower income individuals. The author suggests that increased access to credit combined with a lack of awareness could cause debtors to become over-indebted.

The issue of overOindebtedness has become political in nature with both South Africa's biggest trade union the Congress of South African Trade Unions (COSATU) and the South African Communist Party (SACP) calling for increased 
regulation and removai vi all ucuı nuı cau uaı iv (Jara, 2005).

The National Loans Registry, mandated in the Exemption Notice to the Usury Act, was intended to prevent over-indebtedness, but irregular updates and questionable data quality have limited its usefulness (Ebony Consulting International, 2003). The more recent National Credit Act tackles the problem of over-indebtedness by placing the onus of assessing affordability on the lender, and outlawing reckless lending (National Credit Act, 2006). It also attempts to increase consumer protection by controlling some of the practices of the credit bureaus.

\subsubsection{Causes of Default}

In the first South African study of its kind, Pearson \& Greef (2006) analyse the causes of default in housing microloans. They find that over-indebtedness is a strong contributing factor, and that this is often linked to a lack of financial education. This lack of financial education is also apparent in the FinScope 2005 survey which finds that $37 \%$ of people surveyed have never heard of interest rates, and an additional 23\% have heard of them but don't know what they are.

The preceding discussion illustrates some of the dynamics of the low income market, and suggests that businesses serving this sector face unique challenges. The next section discusses the dynamics of lending from a industry point of view.

\subsection{Profit and Loss: The Dynamics of Lending}

This section describes some of the important aspects of lending as they apply to retail microloans. 


\subsubsection{Credit Risk}

Koch \& Macdonald (2003) describe credit risk as the risk associated with the quality of assets and the likelihood of default. It is the potential reduction in income due to either non-payment or delayed payment. This risk is dependant on both broad economic conditions and the individual debtors personal situation. The credit policy in place at a lending business attempts to deal with both these aspects.

Credit policy is founded on predicting future losses. Expected losses are typically calculated by analysing historical trends and applying these trends to similarly characterised active loans. The main characteristic used for identifying similar loans is the arrears status of the account. These results are then used to cater for future losses (in the form of provisions) thus ensuring the correct levels of capital adequacy (Repullo \& Suarez, 2004).

\subsubsection{Credit Scoring}

The primary way of controlling risk is through identifying high risk clients before lending to them. However, a credit policy that is too strict will limit the number of potential customers and thus limit profits. One that is too loose will result in losses through bad debt and will thus reduce profits.

The most common way to ensure accuracy in client assessment is through credit scoring. Credit scoring is a statistical technique that isolates the effects that different characteristics of the loan applicant have on the likelihood of default. Models (called application scorecards) are developed to use data that represents a 
client's current financiaı pusıuиı (usuany pıvıucu vy uı client), as well as data on the client's past payment behaviour (this is drawn from credit bureaus).

Credit scoring provides a form of automated credit screening and has the benefits of efficiency, consistency and increased accuracy (DeVaney \& Lytton, 1995; Thomas, 2000). Jacobson \& Roszbach (2003) discuss their findings that scorecards have certain limitations - they are generally designed to minimise the risk of default, not to maximise profitability, but loans that would default late in their term are still likely to be profitable.

\subsubsection{Credit Bureaus}

Credit bureau data on consumer lending and payment behaviour has become increasingly important to credit providers as a way of measuring credit risk. The data is used as a source of payment history of potential clients. The availability of this data has enabled credit to be granted to many individuals who would not qualify otherwise (Barron \& Staten, 2000). There are numerous credit bureaus active in South Africa. Two of the largest, TransUnion ITC and Experian, produce their own risk scores that are made available to lenders for a fee. Research by Chandler \& Johnson (1992) finds that bureau based scores are highly predictive of financial risk.

Scores from credit bureaus are often used as an input to credit policy when deciding who to lend to. However, when considering the repayment hierarchy described by both PIC Solutions (2006) and Bollapragada \& Nair (2001), their use may be limited in the case of microloans. According to the repayment hierarchy, microloans tend to be repaid last, after any housing, car and utility bills. This 
means that bureau suvic illay ivi ne niculuuve ui imminent problems on a microloan, as it is these loans that tend to be the first to go bad. This means that any problems will manifest at the lender first, and then appear at the bureau. Home loans, by contrast, will often be flagged for future problems by detecting poor payment on other debts at the bureau.

\subsubsection{Risk Based Pricing}

Credit scoring allows loans to be priced according to risk (Thomas, 2000). This is the practice of charging each borrower an interest rate that is based on their credit risk rather than charging a single rate for all clients. It allows loans to be granted to individuals who would normally not qualify, thus increasing supply of credit (Valentine, 1999). Typically, high risk clients are charged a higher interest rate in order to cross-subsidise the losses experienced on other high risk clients.

\subsubsection{Profitability and Net Present Value Modelling}

Earning profits from lending is a balance of risk and return. Returns come in the form of loan interest, administration fees and insurance fees (Hawkins, 2003; Koch \& Macdonald, 2003) while risk is predominantly in the form of (potential) nonpayment of capital and interest (Koch \& Macdonald, 2003). Carling, Jacobson \& Roszbach (2001) state that expected return depends on interest rate, amortisation scheme, fees paid, fixed and variable costs incurred by the lender, probability of default and loss of principle if default does occur.

The profit margin (PM) of a retail loan can be modelled using the present value (PV) of future cash flows (Stirling, 2000), using a discount rate of either the bank's 


$$
P M=\frac{P V(\text { Payments })-P V(\text { Costs })}{\text { Capital }}
$$

\section{Equation 1: Actual Profit Margin}

Costs include administration, collections and recovery costs, while revenue takes into account missed payments due to default (i.e. credit risk).

\subsubsection{Lending to the Low Income Market}

Daniels (2001a) finds that the ability to repay debt is low and declining at the bottom end of the income distribution. Low income consumers have few assets or financial reserves and are thus more vulnerable to unexpected external events or changes in personal circumstances.

In an analysis of causes of default in housing microloans, Pearson \& Greef (2006) observe a strong correlation between over-indebtedness and default. Their analysis, based on data from a large credit bureau, showed that over $20 \%$ of all loans were more than 90 days in arrears.

Businesses serving this market tend to have higher operating costs and higher bad debts, thus requiring strong credit and collections management (PIC Solutions, 2006). If the increased risk exposure is not well managed significant financial losses can occur, as was the case with both Unifer and Saambou in 2002 
(Schoombee, 2004).

\subsection{Collections Strategy}

\subsubsection{The Role of Collections}

The collections area within a lending business performs an important function and can help increase profitability by minimising losses due to bad debt (Ward, 2005a). The objectives of collections are described as follows (Rial, 2005; Shortbridge, 2006):

o To bring late accounts up-to-date.

o To minimise losses on clients who cannot pay.

o To maintain and enhance customer service

o To minimise operational costs

These objectives are typically attained through a defined collections strategy that makes use of different forms of client contact (written, telephonic or personal) as well as through varying the tone, content and frequency of communication (Rial, 2005; Sutton, 1991).

Collections effectiveness is typically measured on the following metrics (Rial, 2005):

o Delinquency rates. This is a measure of the percentage of the loan book in different arrears buckets. An arrears bucket is a way of identifying accounts with similar stages of delinquency. For example, all accounts 
that are one payııı vсıиı suıсuиı vvı ve in arrears bucket one.

o Roll rates. This is a measure of the percentage of accounts that move from one arrears bucket to another. If an account in arrears bucket one misses another payment, it will move to arrears bucket two.

0 Write off rates. This is the percentage of the loan book that is deemed to be unrecoverable. The loans are written off as bad debt. There can be some post write-off recovery.

There are two possible eventual outcomes to the collections life cycle - the account can be rehabilitated (cured) by repaying any missed payments or the account can be written off (Bailey, 2002).

\subsubsection{Segmentation \& Behaviour Scoring}

Collections departments are inevitably resource constrained and it is generally impossible to work all accounts at the level of intensity that is required to guarantee payment from the client. It is also too expensive to do this. The usual approach is to segment the collections book in some way so that different clients are treated differently. These treatments include considerations of cost, effectiveness and availability of resources (Rial, 2005).

A common approach is to segment by risk by using a behavioural score (Rosenberg \& Gleit, 1994). In this case, a scorecard is developed to predict the likelihood of the client paying their late debts. Clients who are likely to pay are treated as low priority and the tone of any communication tends to be quite gentle. Clients who are unlikely to pay are treated as high priority and communication 
tends to be quite tougı. vvalu (<uvva) suyycoss uviınining this approach with the reason for the client's default to identify the appropriate strategy. For example, if the client is over indebted he suggests the objective should be to establish regular payment, but if this is not possible, the recovery process should be initiated (the recovery process is the final stage of collections and involves initiating legal processes to recover the outstanding debt)

\subsubsection{Collections Strategy}

Collections strategy can be understood to be a series of collections actions that a creditor takes to recover late payments from a debtor. This can take many forms, and includes actions (or combinations of actions) such as sending a letter or making a call (Rosenberg \& Gleit, 1994), as well as the tone and content of any communication and the resources applied to convey that message to the client.

A common method for determining the best collections strategy is testing, where a variety of different strategies are applied to similar accounts. The strategy with the best cost-benefit performance over a period of time is then adopted and tested against new strategies. Organisations that use this approach are typically able to improve performance by 10 per cent each year (Rosenberg \& Gleit, 1994; Ward, 2005a). This approach is particularly useful as it is often not easy to tell which actions or combination of actions taken on an account are most likely to yield the best results (Ward, 2005a). As Rial (2005) states, collections strategy is both an art and a science.

Collections strategy is made up of a number of actions and timings of actions, all designed to result in a particular outcome. In this research study, a distinction is 
made between two disuı suaıсyıсs uı aıı ı auı

Arrears based collections attempts to get the client to catch up any missed payments immediately, while behaviour based collections seeks to ensure the client starts paying his instalments regularly and only catches up missed payments when he is able to do so. These two strategies are now discussed in greater depth.

\subsubsection{Arrears Based Collections - The Traditional Role}

The collections function is traditionally used to mitigate credit risk on the loan book. Initial credit policy prices the loan for a certain level of bad debt. It is up to collections to ensure that the acceptable levels of debt described by policy are met or beaten (Bailey, 2002). This risk-oriented view encourages collections managers to focus on the status and size of different arrears buckets, as well as the age of the debt. Accounts are typically grouped by arrears bucket, with different teams and strategies assigned to each bucket. All collections communications will attempt to collect on all late payments at the same time. Indeed, all the literature on collections best practice advocates this approach (see, for example, Bailey, 2002; Rial, 2005; Ward, 2005a; Shortbridge, 2006). This approach fails to take into consideration payment behaviour; clients who have paid many months in succession are still contacted for a payment they missed many months previously.

\subsubsection{Behaviour Based Collections - An Alternative Approach}

A certain amount of flexibility is recommended in collections strategy. For example, when faced with affordability constraints, the debt collector can make an arrangement whereby the debtor pays less than is due (Bailey, 2002). This is 
usually treated as an acıuı u ı ı⿻ ıсsuı. vvısuı, uummers \& Hope (2000) find that current payment behaviour is a good predictor of future payment behaviour, suggesting that arrears status per se is not the only way of measuring credit risk. There may be merit in collecting next instalment due only. This approach, referred to as behaviour (or recency) based collections, encourages the client to make the next payment due and only repay the arrears if he is in a position to do so. The previously missed payment may be forgiven until the end of the term of the loan, though it will still earn interest. This places less pressure on the client who may be in financial difficulty, and delays repayment until the client is able to pay. Certain successful credit providers to the low income market use this collections strategy (Pearson \& Greef, 2006).

Payment behaviour based collections may have the added benefit of improved customer relations. There is less pressure on the client to catch up a missed payment as the focus is on the next payment only. Even slow-paying, marginal credit risk clients may be profitable, and it is important not to lose these customers to competitors as it is cheaper to retain a customer than it is to find a new one (Spinks \& Wells, 1997). Amicable rehabilitation of overdue accounts is a primary concern for the collections function (Rial, 2005). Ward (2005a) discusses the importance of following different collections strategies according to the reason for the client defaulting. He observes that for client's who are over-indebted it is most important to establish regular payment.

This down-side of this approach is that that fewer clients improve from one arrears bucket to another. This is at odds with standard risk measurement methodologies 
(described in sectioı c.c.1) vvıluı usc alıcaıs sudtus as the basis of all

provisioning. In a 2006 article, PIC Solutions describe how behaviour based collections is sometimes followed in sub-prime markets. The article also cautions against using payment behaviour as a basis for provisioning against bad debt as this overstates the quality of the book. The article does not discuss the merits of driving collections strategy with this approach, nor does it mention the impact on profitability.

A behaviour based collections strategy may have a different cost structure to an arrears based strategy. For example, a client who is paying regularly but is in arrears will not be in collections. In addition, a client who has paid recently, after missing a payment, is seen as a lower risk than a client who has just missed their first payment and may not be called at all. In a simple arrears based strategy both of these clients could be treated in a similar fashion.

For the sake of clarity, note that behaviour based collections and behavioural scorecards are unrelated. Behaviour based collections describes the emphasis of the collections strategy employed, while a behavioural scorecard describes a risk prediction approach. There is nothing to stop a behavioural scorecard from being used with an arrears based collections strategy.

\subsubsection{Collections and Profitability}

Behaviour based collections may impact on profitability as it effects the payment pattern on a loan. Carling, Jacobson \& Roszbach (2001) mention that bad debtors pay more interest, as amortisation is slower than on a good loan. The authors also describe the fact that losses are diminished as they realised in the future, and 


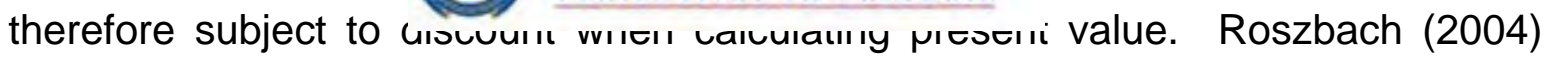

describes the fact that the profitability of a loan is not dependent on whether the account defaults or not, but rather on the duration of repayments, the amortisation scheme and collections costs. This is because a loan is a multi-period contract, and the present value is determined by the number of repayments received. If the loan defaults late in the term, the present value of payments already received may make the loan profitable.

Profits can also be maximised by controlling costs. Behavioural scores can be used to identify clients that are most likely to pay, and collections efforts can be reduced for those clients (Rosenberg \& Gleit, 1994). Clients that are also unlikely to pay regardless of actions taken can also be identified. These clients can be written off to save any additional collections expense (Lane, 1972).

Kim \& Atkins (1978) provide a model for maximising the profits of accounts receivable by examining the impact of credit lengthening strategies. This model uses NPV of deferred sales, and assumes that credit lengthening does not include interest.

This approach can be modified and applied to collections strategy. Behaviour based collections yields more revenue than arrears based collections when the present value of the probable repayment at the end of the term exceeds the present value of the probable repayment in the following month. This is illustrated in the following equation: 


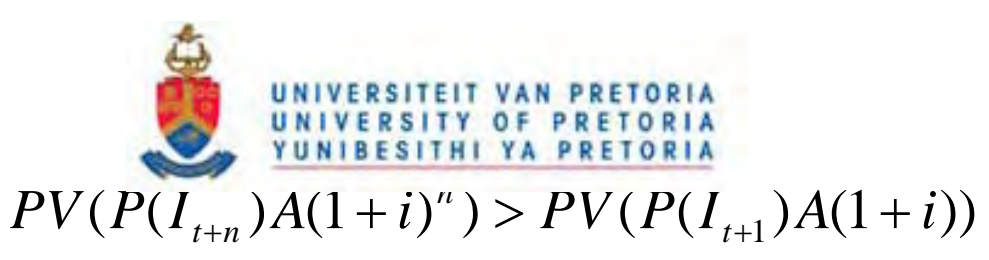

\section{Equation 2 Probable Income}

where:

$$
\begin{aligned}
& P V=\text { present value } \\
& P\left(I_{t+1}\right)=\text { probability of receiving requested payment next period } \\
& P\left(I_{t+n}\right)=\text { probability of receiving requested payment at end of the term } \\
& A=\text { arrears amount } \\
& t=\text { current period } \\
& n=\text { periods until end of term } \\
& i=\text { interest per period }
\end{aligned}
$$

The above equation illustrates that it can be more profitable to defer repayment of the arrears amount. When interest rates are significantly higher than the cost of capital (the discount factor), as is the case with microloans, this can even occur when the probability of repayment at the end of the term is lower than the probability of repayment in the next month.

\subsubsection{Loss of Income}

The Collections function attempts to minimise the loss that occurs on defaulted accounts. One way to measure this is to measure the actual cash flow on a defaulted loan against the expected cash flow from the same loan. This measure, introduced in this research, is referred to as the cash flow margin and is defined by 
the following equation.

$$
C F M=\frac{P V(\text { Actual_Payments })-P V(\text { Expected_Payments })}{P V(\text { Expected_Payments })}
$$

\section{Equation 3 Cash Flow Margin}

This metric is an appropriate measure in collections as it clearly illustrates the losses that collections is trying to mitigate. It is also independent of loan capital and product design considerations, which are two factors over which collections exerts no control.

\subsubsection{Cost to Collect}

The collections department needs to keep close tabs on the cost to collect, and any collections strategy should find the balance of applying the cheapest action to get the maximum results (Rial, 2005).

There are many costs to consider in the collections environment, the most significant of which is staff, usually accounting for $60 \%$ of costs (Rial, 2005). The staff's primary function is to contact the debtor and apply the collections strategy, be it immediate recovery of the arrears or a negotiation around the next payment. The best measurement of productivity in this case is right party contact, RPC, which is a count of the number of contacts made with the debtor.

\subsection{Conclusion of the Literature Review}

Growth in bank microlending is unlikely to slow in coming years as this market is 


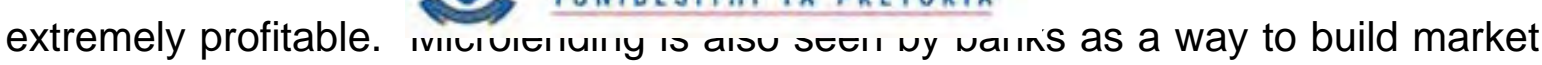
share in the low income market and to subsequently cross sell products that will help them fulfil their mandate in terms of the financial services charter. Changes in legislation and a downturn in the economy are likely to place pressure on current profit levels and institutions are will need to identify ways to contain their risk while maintaining profits.

Those clients who do miss repayments end up in the collections department of the bank. Existing literature and industry best practice suggest that the role of collections is to cure delinquent accounts as quickly as possible. Profit is maximised through minimising costs and maximising the amounts recovered. (Rial, 2005). This approach is founded on credit management techniques developed and perfected in established economies, and largely on credit card debts to middle income earners. There has been no empirical work done on microloan clients, and as the dynamics of this market may be significantly different to the market for credit cards, this suggests a need for research in this area.

The low income market tends to be vulnerable to over-indebtedness, and has little capacity to deal with external shocks. Anecdotal evidence suggests that when a client misses a repayment on her loan, she is unlikely to be able to catch up the missed payment, and pressurising her to do so may result in the her taking on more debt. In this case there is a suggestion that allowing a client to pay next instalment only can have a beneficial impact on the long term viability of the loan relationship. This approach to collections is called behaviour based collections and is the focus of this paper. 


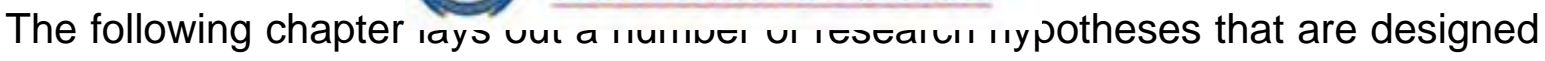
to test the impact of this form of collections on both revenue, costs and eventual collections outcome. 


\section{Chapter 3: Research Hypotheses}

The literature review identifies a number of areas for investigation. Firstly, the impact that collections strategy, be it behaviour or arrears based, has on the cash flow margin of a loan in default needs to be understood. Secondly, the impact that collections strategy has on eventual collections outcome should be examined. Thirdly, how collections strategy impacts on costs, and finally, how the cash flow margin varies with changes in credit risk from the time the loan was booked to the time the loan defaulted should be investigated. An understanding of these four aspects will expand the pool of knowledge of the collections function and will enable businesses to tailor their strategies to maximise profits.

Based on the literature review, the following hypotheses are made:

Hypothesis 1: The null hypothesis states that for defaulted microloans, the mean cash flow margin of accounts that are collected on using behaviour based collections is not significantly different to the mean cash flow margin of loans that are collected on using arrears based collections. The alternative hypothesis states that the mean cash flow margin is different for accounts collected on using the different strategies.

$\mathrm{H}_{0}: C F M_{B B C}=C F M_{A B C}$

$\mathrm{H}_{\mathrm{A}}: C F M_{B B C}<>C F M_{A B C}$

Hypothesis 1a: The null hypothesis states that for defaulted microloans that subsequently cure, the mean cash flow margin of loans collected 
on USıı' a veııavivuı nascu suaıcyy is not significantly different to the mean cash flow margin of loans collected on using an arrears based strategy. The alternative hypothesis states that for the above loans there is a significant difference in the mean cash flow margin of loans that are collected on using the different collections strategies.

$\mathrm{H}_{0}: C F M_{\mathrm{BBC}}$ of cured loans $=C F M_{\mathrm{ABC}}$ of cured loans

$\mathrm{H}_{\mathrm{A}}:$ CFM $M_{\mathrm{BBC}}$ of cured loans $>C F M_{\mathrm{ABC}}$ of cured loans

Hypothesis 1b: The null hypothesis states that for defaulted microloans that subsequently write off, the mean cash flow margin of loans collected on using a behaviour based strategy is not significantly different to the mean cash flow margin of loans collected on using an arrears based strategy. The alternative hypothesis states that for the aforementioned loans there is a difference in the mean cash flow margins for loans collected on using different strategies.

$\mathrm{H}_{0}: C F M_{\mathrm{BBC}}$ of written off loans $=C F M_{\mathrm{ABC}}$ of written off loans

$\mathrm{H}_{\mathrm{A}}: C F M_{\mathrm{BBC}}$ of written off loans $<>C F M_{\mathrm{ABC}}$ of written off loans

Hypothesis 2: The null hypothesis states that for defaulted microloans, the outcome of collections using a behaviour based collections strategy is not significantly different to the outcome of collections using an arrears based collections strategy. The alternative hypothesis states that the collections outcome differs according to 
collecuvis suaicyy curpivycu.

$\mathrm{H}_{0}$ : Collections Outcome ${ }_{B B C}=$ Collections Outcome ${ }_{A B C}$

$\mathrm{H}_{\mathrm{A}}$ : Collections Outcome ${ }_{\mathrm{BBC}}<>$ Collections Outcome ${ }_{\mathrm{ABC}}$

Hypothesis 3: The null hypothesis states that for defaulted microloans, the cost to collect when using a behaviour based collections strategy is not significantly different to the cost to collect when using an arrears based collections strategy. The alternative hypothesis states that the cost to collect differs according to collections strategy employed.

$\mathrm{H}_{0}:$ Cost $_{\mathrm{BBC}}=$ Cost $_{\mathrm{ABC}}$

$\mathrm{H}_{\mathrm{A}}:$ Cost $_{\mathrm{BBC}}<>\operatorname{Cost}_{\mathrm{ABC}}$

Hypothesis 4: The null hypothesis states that for defaulted microloans that are collected on using a behaviour based strategy, there is no significant relationship between the cash flow margin and the change in credit risk from when the loan was granted to when the loan defaults. The alternative hypothesis states that there is a significant relationship between the cash flow margin and the change in credit risk.

$\mathrm{H}_{0}$ : $C F M_{\mathrm{BBC}}$ does not vary in accordance with change in risk between loan grant date and default date.

$\mathrm{H}_{\mathrm{A}}: C F M_{\mathrm{BBC}}$ varies in accordance with change in risk between loan 
Hypothesis 4a: The null hypothesis states that for defaulted accounts that are collected on using an arrears based strategy, there is no significant relationship between the cash flow margin and the change in credit risk from when the loan was granted to when the loan defaults. The alternative hypothesis states that there is a significant relationship between the cash flow margin and the change in credit risk.

$\mathrm{H}_{0}: C F M_{A B C}$ does not vary in accordance with change in risk between loan grant date and default date.

$\mathrm{H}_{\mathrm{A}}: C F M_{\mathrm{ABC}}$ varies in accordance with change in risk between loan grant date and default date.

All the above hypotheses are tested at a significance level of $5 \%$. 


\section{Chapter 4: Research Method}

This chapter covers the research method adopted to test the hypotheses in

Chapter 3. It includes the approach taken to identify the appropriate population, the sampling method used, the data collection process and the approach taken to the data analysis. It also details limitations of the research method as well as some issues around data integrity.

\subsection{Research Design}

The research was designed around the use of secondary data. Two loan books were available for analysis, from different business units at a large bank. Both loan books consisted of microloans predominantly to the low to moderate income market. The first book, Book 1, was from a business that collected on defaulted accounts using a behaviour based collections strategy. The second book, Book 2, was from a business that used an arrears based collections strategy.

The research was designed to measure differences in cash flow, collections outcome and costs due to different collections strategies. Metrics for different client segments were compared across both books. A rigorous approach to sample matching was employed to ensure that the samples from the two books were comparable and differences in results would be due to collections strategy only. Once matching was complete, appropriate financial measures were defined and applied to the loan books. These measures were then compared using statistical techniques. The research was well suited to a quantitative approach as the original data already existed and the analysis was done using established 


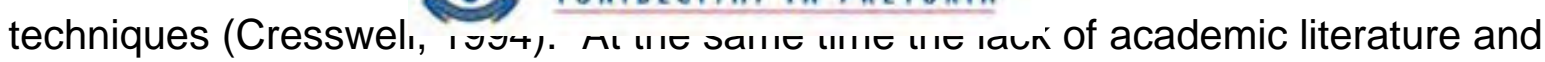
previous empirical studies meant that a certain amount of exploratory work had to be conducted as well, particularly in defining appropriate metrics.

\subsection{Unit of Analysis}

The unit of analysis was an individual microloan that was booked after 01 January 2003 and was closed, either due to being paid up or by being written off, before 01 October 2006. Each microloan had the following additional characteristics:

- The loan had been in default, defined as being at least two payments behind schedule, at some point during its term. While an account would have entered collections when it was one month in arrears, this might have been for technical reasons (for example a late salary), or because the client simply forgot to pay. In either case the client would typically pay immediately upon being notified of their account status so these accounts were not considered to be true reflections of collections accounts.

- The client had not experienced any unusual events such as death, disability, retrenchment, fraud or a jail term that would have fast tracked the account to insurance, legal or write off states.

\subsection{Population}

The population of relevance was all retail microloans in the formal lending sector in South Africa where the account had been in default at some point during its term. This meant that the loan value was not greater than R10,000 and the loan term was not greater than 36 months. 


\subsection{Sampling Methıu aıı vi<c}

While the population defined above is quite broad, the availability of data and the data analysis requirements meant placing a number of judgemental constraints on the sample. These are detailed in the following sections.

\subsubsection{Initial Sample}

The data sample was drawn from the two loan books described in section 4.1. This sample was based on convenience and access to data. From this dataset, all available data points that met the following criteria were used:

1. The loan was booked after 01 January 2003 as this is when behaviour based collections was initiated on Book 1.

2. There was no early legal or write-off process due to fraud, jail term, etc

3. There were no insurance claims on the account. This excluded accounts that were affected by death, disability or retrenchment from the sample.

4. The account was closed before 01 October 2006 (meaning it had reached the end of its term or had been written off). This was necessary to ensure that the full payment record on the account could be measured.

5. The loan was in default at some point during its term. The definition of default was that the loan was at least two months in arrears.

6. The collections department had telephonic contact with the client. This ensured that the collections strategy being followed was actually experienced by the debtor. It also ensured that any fundamental differences 
in client contacıanııı uı uaıa yuaııy u u ı ıvv ıvan books were ignored.

There were 17,526 accounts that met the above criteria in Book 1, and 12,666 accounts that met the above criteria in Book 2.

\subsubsection{Matched Sample}

The research was designed to measure differences in cash flow, collections outcome and collections costs due to different collections strategies. However, the data for the two samples were from independently managed business units, and so there could have been a number of reasons for any differences in results. For example, different customer bases, credit policies, or different loan sizes could influence actual cash flow and the client's ability to repay the loan. To isolate the role of collections strategy, a number of additional criteria were applied:

1. The client's salary at application time was equal to or greater than $\mathrm{R} 2,000$ per month and less than or equal to R7,000 per month.

2. The loan size was equal to or greater than $\mathrm{R} 3,000$ and less than or equal to $\mathrm{R} 7,000$.

3. The loan term was either 12 or 24 months. This was necessary as there were very few loans with a term of 36 months in Book 2.

4. For Book 1 the application bureau score was greater than 490 and less than 688, while for Book 2 the application bureau score was greater than 622 and less than 747. The reason for the different range was that the different business units used different bureaus to supply them with scores. In both cases, the top and bottom $20 \%$ of bureau scores were 
The above criteria were strict but necessary to produce a sample of accounts that could reasonably be compared to each other, with the only significant difference being that of collections strategy employed.

After the criteria were applied there were 2,514 accounts from Book 1 and 2,470 accounts from Book 2. Table 5-1 shows characteristics of the accounts both before and after matching.

\subsection{Data Collection Process}

The data collection process took place over a number of stages. The first stage was concerned with preliminary account identification, based on the criteria defined in section 4.4.1 above. The second stage identified an equivalent set of good accounts for each loan book. These accounts had never been in default and were to used as a control sample. Stage three was concerned with identifying a matched set of accounts from the two loan books. The fourth stage of data collection was concerned with calculating the fields required for testing the different hypotheses.

\subsubsection{Stage 1: Account Identification}

There were eight data sources to work with, four for each business unit. Each business unit had the following databases:

- An application database that stored all application-time information. This was used to provide client information at the time the client applied for 
the loan.

- A transactional database that stored all payment history on the loan accounts, as well as the latest client and loan information.

- A collections database that provided a history of all activity of the collections department.

- A central reporting database that stored transformed data from all the other sources. This was the primary source of data but the other three sources were used to check data integrity, as well as investigate any issues.

The process outlined below was followed on each loan book to identify the relevant accounts and records:

- The transactional records were used to identify all microloans that were active during the relevant period and were now closed for the appropriate reason.

- Application tables were used to provide all client demographics and application bureau scores for the loans identified above.

- Collections records provided information on whether contact had been made with the client or not, as well as how many times this happened.

Once the records had been identified, the following steps were taken to clean the data:

- All unique identifying information was removed from the data so that 
- Records with missing financial data were excluded

- All outliers were removed.

This aspect of the data collection process, as well as data integrity, is discussed in greater detail in section 4.8 .

\subsubsection{Stage 2: Good Accounts}

The next step in the data collection process was to identify a set of good accounts. These were accounts that were unaffected by collections strategy and could thus be used as a control sample. All the criteria used to identify defaulted accounts were applied, with the only difference being that the control accounts had never entered collections, nor been in arrears.

\subsubsection{Stage 3: Account Matching}

The account matching process was designed to make sure that the two samples had customers with similar risk profiles, and to ensure that a customer from one business would have been granted a loan from the other business had they applied for one. This was done by considering demographic, product and credit bureau information.

Identifying appropriate demographic and product characteristics was an iterative process that compared statistical characteristics of the two samples to ensure similarity. In all cases, the extreme ends of any range were avoided. For example, the businesses offered loans from R500 to R10,000 in size, but only loans in the 
range $R 2,000$ - R7,0lu vveıc vuısıucıcu. Lauı ıaııe was set by examining the frequency distribution and selecting end points that were away from the extremes and resulted in similar distributions. Table 5-1 shows the results of this process.

\subsubsection{Application Score}

To establish an appropriate range for the application score was a more complex process. The data from the two books could not be directly compared as the data was from different sources: Book 1 used a bureau score from a company called Experian, while Book 2 used one from a company called ITC. Both bureau scores predicted credit risk, but the actual score ranges differed. The principle used was to exclude the top and bottom $20 \%$ of all accounts in each portfolio to ensure that the samples contained middle of the range customers. The following steps were taken:

- The bureau scores of all accounts (both "default" and "good") identified in stage 1 and stage 2 were examined. The accounts were ordered by bureau score and the top and bottom 20\% accounts were discarded. This ensured that there were no "marginal" clients included in the sample that may have been rejected by the credit policy at the other business, or may have been ranked differently by the two bureaus.

- The remaining accounts were then split into equal sized groups (with the same number of accounts in each group), and the score of the account at each cut-off point was used to identify the score split.

- Accounts within each score range were then assigned the same application 


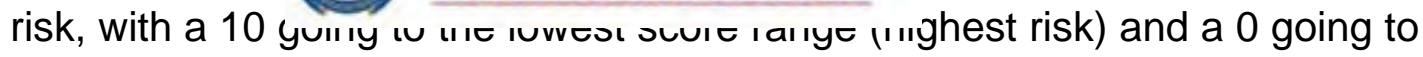
the highest range (lowest risk).

The end result was a relative risk scale based on the range of scores found on successful loans. Appendix 1 illustrates the above process and provides details on the application risk spread of accounts.

\subsubsection{Stage 4: Calculated Fields}

A number of the fields required by the research needed to be calculated. The following sections describe how this was done.

\subsubsection{Cash Flow Margin}

The research required the use of a metric that was independent of product design. Since parts of the research were attempting to measure the impact of collections strategy on cash flow, two different loans that exhibited exactly the same payment behaviour needed to yield the same result. Metrics such as net present value and profit margin were affected by interest rates, admin fees and loan size, as shown in

Table 4-1 below. A new metric was designed, called cash flow margin, that measured cash flow independently of product design. This is defined in section 2.3.7, but repeated below for ease of referencing. Example behaviour of this metric is illustrated in

Table 4-1 below. 
Illustrating a number of loan metrics (net present value, profit margin and cash flow margin) Only cash flow margin presents identical results for two different loans with the same repayment pattern.

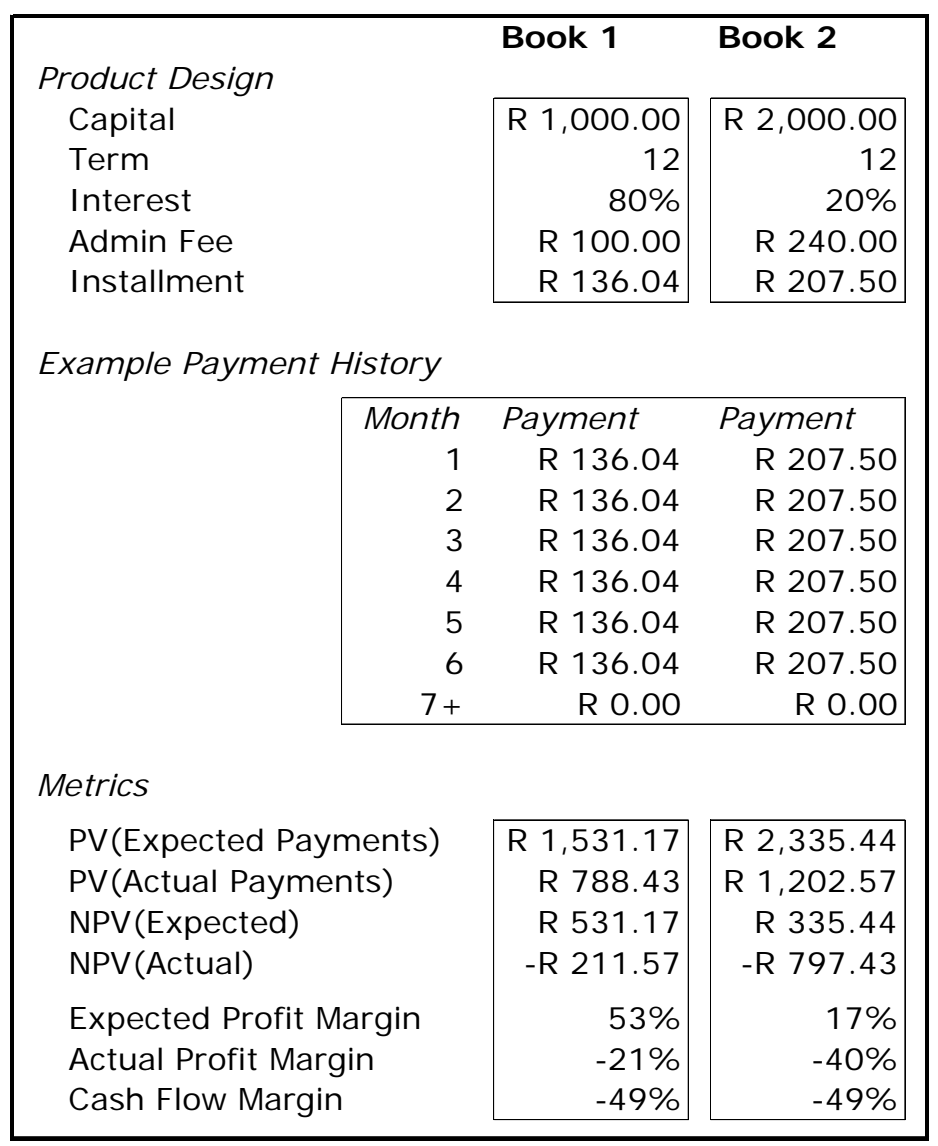

\section{Note}

A discount rate of $12 \%$ was used in the present value calculations.

The Expected and Actual Profit Margins are defined in Equation 1 and include the capital amount. Cash Flow Margin is defined in Equation 4 and is independent of pricing and capital.

$$
C F M=\frac{P V(\text { Actual_Payments })-P V(\text { Expected_Payments })}{P V(\text { Expected_Payments })}
$$

\section{Equation 4 Cash Flow Margin}




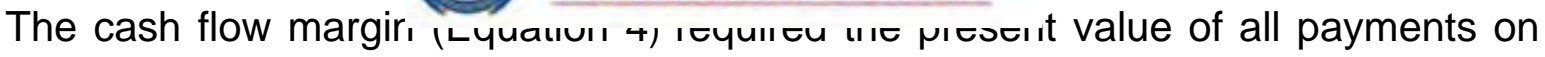
each loan account. In order to calculate this, all financial transactions on the identified accounts were extracted from the host databases and discounted back to the loan grant date. To ensure fair comparison across both books, a number of adjustments had to be made:

- The businesses employed slightly different write off policies, but they both wrote off accounts when the cost of continued collections outweighed the likelihood and magnitude of any further payments. A recovery rate of $10 \%$ was assumed to be realised on all accounts at the time of write off, as this was a reasonable price for a moderately aged bad debt (Waggoner, 2006). This figure was then discounted to the beginning of the loan and added to the present value of the other transactions.

- Book 2 included collections fees on all defaulted loans. Since Book 1 did not use this practice, the present value of fee income was subtracted from the results for Book 2. This was only done if the account was paid up, and not if it was written off, as only these accounts could be considered to have paid the fees as well as the interest and capital.

- A discount rate of $12 \%$ was used as this was seen as a reasonable cost of capital for a standalone business, as well as being approximately half way between the internal rate of return required by both businesses (20\%) and the actual cost of borrowing money from the bank's treasury (linked to the repo rate).

- The cash flow margin for each control sample was calculated and then 


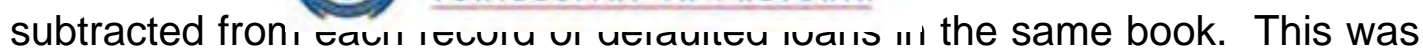
done to further reduce remaining differences in product design or client base.

\subsubsection{Credit Risk at Default - the Behavioural Score}

The credit risk at time of default was required for each book (this is commonly referred to as a behavioural score as it is based on data that is internal to the business and represents the client's past behaviour). The two business units used different behaviour scorecards that predicted different outcomes so it was necessary to define a new behavioural risk metric. The metric that was used was "time to default". This was a measure of the time that the account took to go from being up to date to being in default. Since default was defined as occurring when the account was two months in arrears, an account that went from up to date to default in two months was deemed to be high risk and assigned a score of 10. An account that took 3-4 months to get to default was assigned a score of 5 (medium risk), and an account that took 5 months or more to get to default was scored as a 0 and labelled low risk.

This metric, though coarse, was assumed to be indicative of relative risk and a suitable proxy for behaviour score. The metric was expected to yield the same results across both businesses, as both collections strategies attempt to get the client to pay in the following month, and prevent the arrears status from worsening.

\subsubsection{Change in Credit Risk}

The hypotheses also required a measurement of change in credit risk. There were 


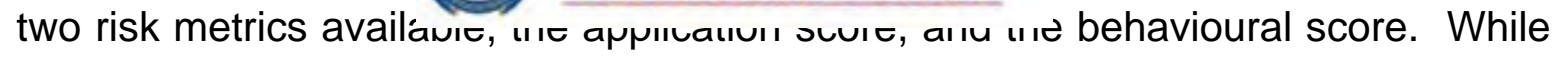
these two metrics are not directly comparable, they both provide a measure of relative risk. The change in credit risk was calculated by comparing the risk measure provided by the application score to the risk measure provided by the behavioural score. The application risk score was subtracted from the behaviour score at the time of default. A positive value indicated that the relative credit risk had increased, while a negative value indicated that the relative credit risk had decreased. Note that these measure were based on relative risk and are not absolute measures. They indicated how an account's risk profile changed relative to other accounts in the same portfolio.

\subsubsection{Cost to Collect}

The number of months in which telephonic contact was made with a client from collections across the loan life cycle was used as a proxy for cost to collect. Counting months in which there were contacts instead of total number of contacts removed the impact of other collections strategy artefacts such as reminder calls when a call is made to a client to remind them of a previous agreement they made.

This metric was appropriate as it aggregated a number of cost contributors, such as:

- The length of time the account was in collections. For example if the account was in default for one month and then cured, it would only have been called once.

- The number of times the loan was in collections. For example if the loan 
cured but then ucıauıcu ayaıı, « vvuuı ı ıve nech called again.

- The success rate of arrangements made with the client from previous calls. If the client kept to the terms of her previous arrangement, she would often not be called again.

For this metric to be valid, contactability of the client would have to be the same across the two samples. This was assumed to be the case as one of the qualifying criteria for the two samples was that the client was contactable at least once.

\subsection{Data Analysis Approach}

A number of different approaches were used for testing the hypotheses. These are described below.

\subsubsection{Cash Flow Margin}

To measure how the cash flow margin varied across the two collections strategies, and if this was influenced by collections outcome, the samples from each book were segmented into four groups. Group 1 was the control sample and consisted of all good loans that met the same criteria as the test sample, but had never been in arrears. Group 2 was all defaulted loans and was the main subject of the research. Group 3 was a subset of Group 2 and consisted of all defaulted loans that had been rehabilitated (i.e. those accounts where the collections strategy had been successful). Group 4 was also a subset of Group 2 and consisted of all accounts that had not been successfully rehabilitated but had been written off instead. Note that as write off and cure were the only two possible outcomes of the collections sample, these statuses were mutually exclusive. 


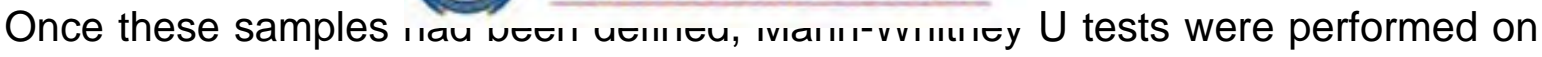
the cash flow margin of each group, using loan book as the grouping variable. The tests were used to determine if the results were statistically different from zero, and were conducted at a 5\% error level. The Mann-Whitney $U$ test was used because the two samples were independent and not normally distributed but had the same probability distributions except for location (Hintze, 2005).

\subsubsection{Collections Outcome}

To measure the relationship between collections outcome (write off or cure) and collections strategy, a simple chi square test was used as this is suitable when making inferences of different categories of data (Welman \& Kruger, 2001). This was tested at the $5 \%$ level and compared the actual number of accounts that were written off or cured for each loan book against the expected values.

\subsubsection{Cost to Collect}

The cost to collect was measured by counting the number of cycles that included a right party contact (RPC) with the client over the term of the loan. The results were not normally distributed so they were tested using a Mann-Whitney $U$ test at an error level of $5 \%$.

\subsubsection{Change in Credit Risk}

The analysis of change in credit risk and the impact this had on cash flow margin was completed in two steps. The first step sought to establish if there was a relationship between change in credit risk and collections strategy. This was done using chi square tests at a significance level of $5 \%$. 


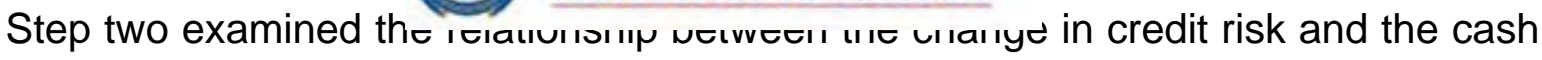
flow margin of the loan. Again this was tested using chi square tests (one on each loan book) at a significance level of $5 \%$.

\subsection{Potential Limitations}

There were a number of limitations to the research method employed. The most significant of these are discussed below.

All loan data available for analysis came from one financial institution. This was a convenience sample, and as such could not be assumed to hold true for the rest of the population of relevance (Welman \& Kruger, 2001). While all bank microlenders serve a similar market, different credit policies, product design, and operational implementation mean that characteristics of clients who are granted credit may differ.

Furthermore, the data representing different collections strategies came from two independent business units. This matching process that was applied to produce samples of data with comparable characteristics placed additional limitations on the inferences that could be made to the population of relevance, as one of the prerequisites of the Central Limit Theorem is that random sampling be used.

There may have been operational influences that impacted the results. For example, differing management styles at the two business units may have affected staff morale, which in turn would have effected the success rate of any collections strategy.

A further limitation of the research is that it used a proxy for cost to collect, in the 


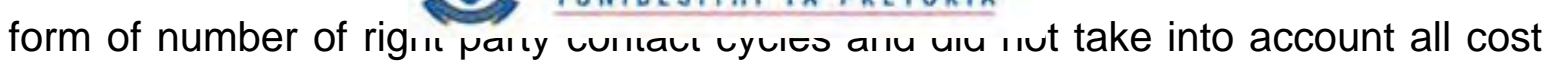

inputs. It also did not consider the opportunity cost of provisioning for bad debt. As the business using behaviour based collections used the arrears status of the accounts as the basis of provisioning, its levels of capital adequacy may have been over-stated.

\subsection{Data Integrity}

The research relied heavily on secondary data from a number of different sources, and therefore required careful screening for inconsistencies. Cross referencing between the different data sources was conducted where possible, and all outliers and unusual results were examined. This process revealed a number of data integrity issues, which are described below:

- In some cases, the loan amount (capital) differed across data sources.

- Some applications did not have ID Numbers, while others had incorrect ones. (This field was used to match financial data to demographic and application stage data).

- Some applications did not have credit bureau scores available.

- In some cases, there were differences in an account's history (start date, date closed, date written off, date of insurance claims) across different data sources.

- Some accounts had been worked in collections despite never missing a payment, while others had missed numerous payments but not been sent to 
collections.

- There were some discrepancies around product set-up data, for example where the instalment and term would not recover the capital amount.

- Certain payments did not appear in the client's statement record, so the actual revenue was understated.

Each issue was investigated and resolved where possible. If the correct data could be ascertained, then those data were used, otherwise the affected records were excluded from the sample. 


\section{Chapter 5: Research Results}

\subsection{Description of the Sample}

Table 5-1 below illustrates the characteristics of the default accounts in each book. It shows the sample both before and after the matching process described in section 4.5.3. The final sample contained 2,514 accounts from Book 1 and 2,470 accounts from Book 2. Client and loan characteristics of the two samples were more similar after the matching process.

Table 5-2 illustrates the same fields for the control sample of good accounts. Appendix 1 shows bureau scores for both loan books and illustrates the process used to identify appropriate cut-off points and risk allocations. 
Characteristics of defaulted accounts from the two loan books, both before and after matching. After matching, the samples were more closely matched along certain key metrics.

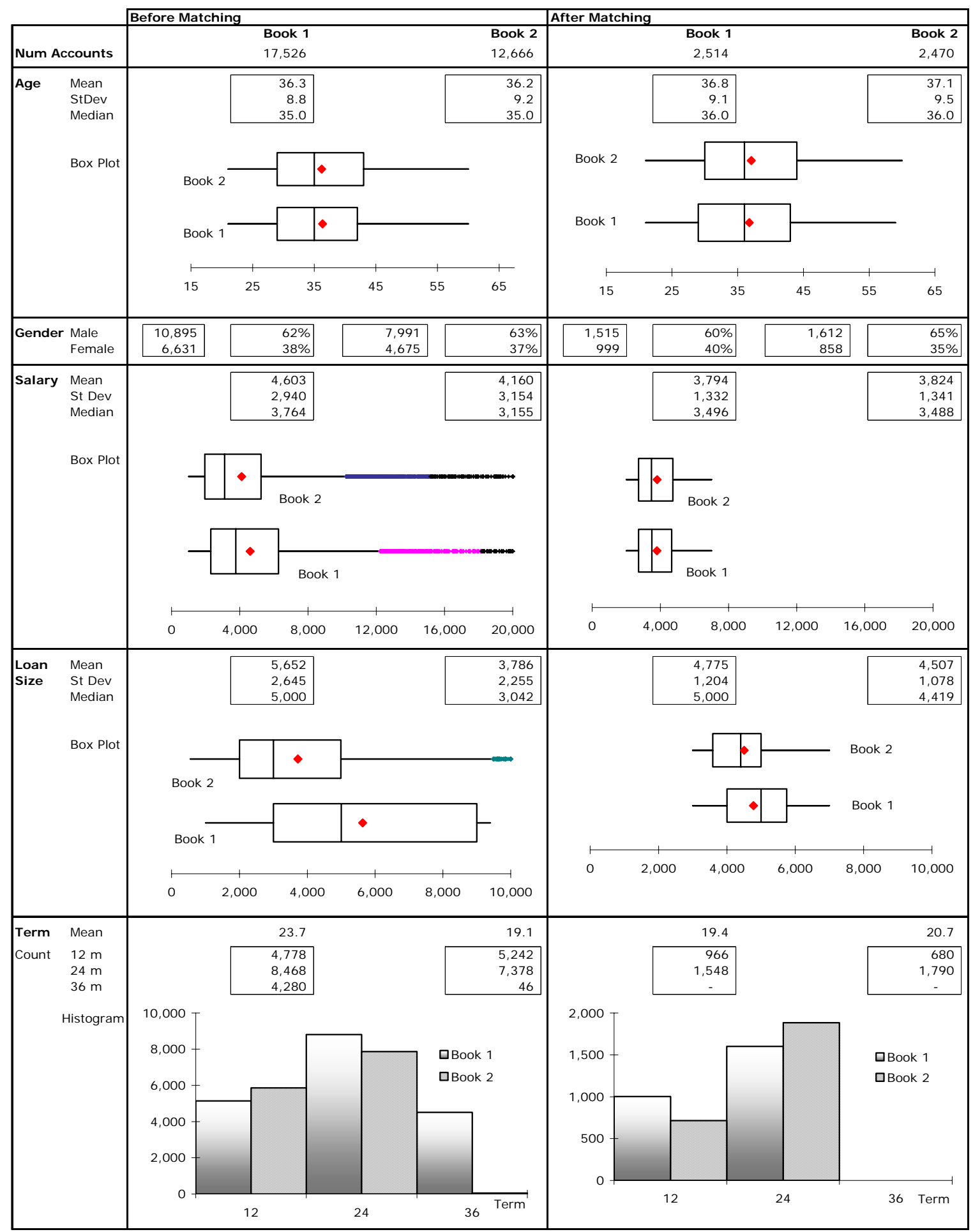




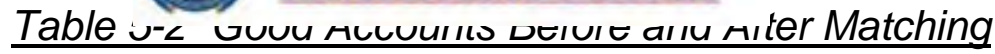

The control samples from the two loan books, both before and after matching. After matching, the samples had more similar values for salary and loan size.

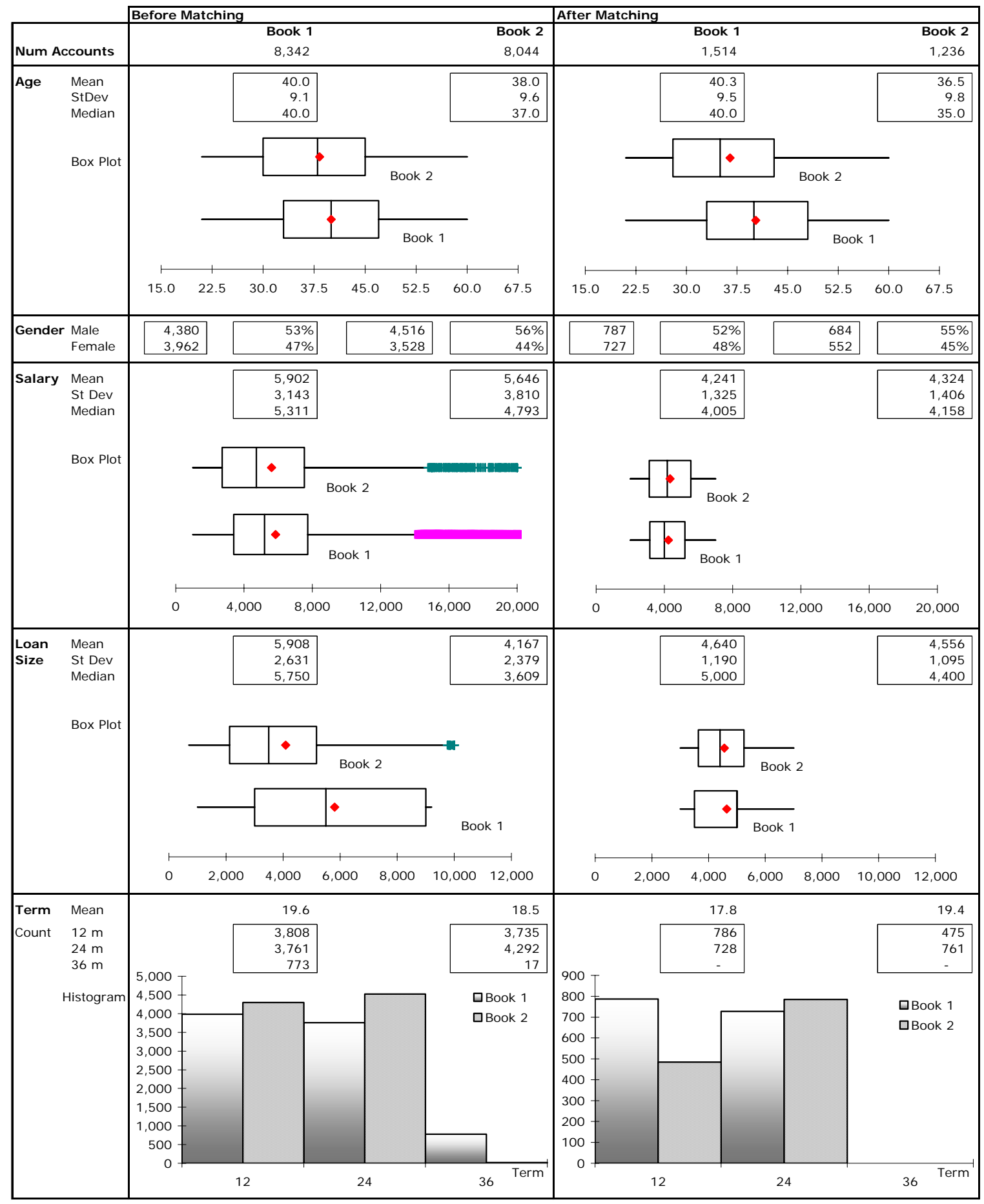




\subsection{Cash Flow Maı y'!}

One of the primary measurements used in the hypotheses was cash flow margin. This measurement was designed to yield a ratio of cash received as a margin on cash expected.

\subsubsection{Mean Cash Flow Margin}

The cash flow margin on defaulted loans was compared across the two loan books. In each case it had a bimodal distribution, as shown in Figure 4 below. This was due to the samples being made up of cured and written off accounts, each of which is clustered around a different mean. Distributions for these groups are shown in Appendix 2.

\section{Figure 4 Cash Flow Margin for Defaulted Accounts}

The distribution of cash flow margin for the two books. The bimodal nature was due to the separately clustered contributions of written off and cured accounts.

Book 1

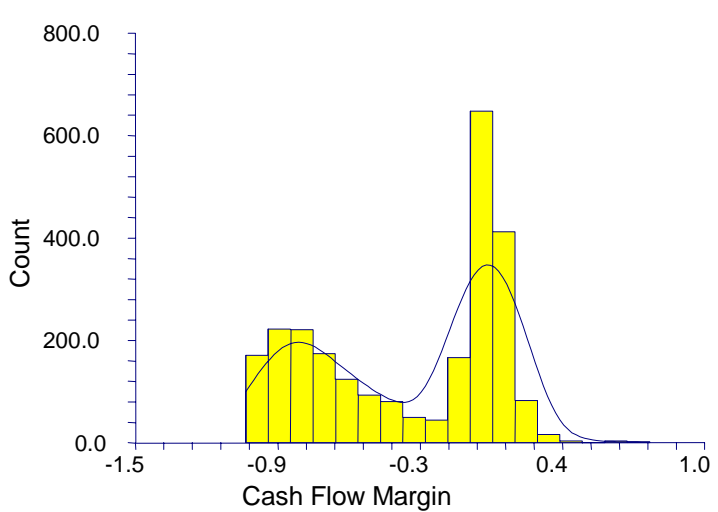

Book 2

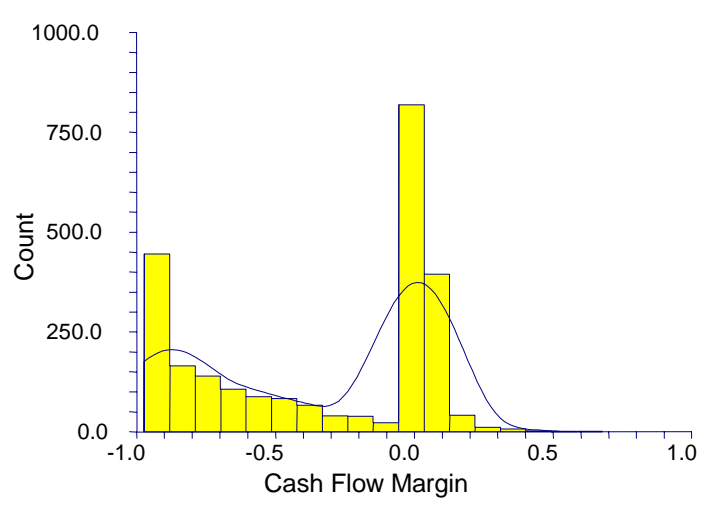


The mean cash flow margin was compared across the two loan books for different segments of the population. The Mean Cash Flow Margin (MCFM) was defined as follows:

$$
M C F M=\frac{1}{n} \sum_{1}^{n} \frac{P V(\text { Actual_Payments })-P V(\text { Expected_Payments })}{P V(\text { Expected_Payments })}
$$

\section{Equation 5 Mean Cash Flow Margin}

where:

$$
\mathrm{n}=\text { number of loans }
$$

Table 5-3 below shows the results for the mean cash flow margin across the different account groups analysed, namely good accounts, defaulted accounts, written off accounts and cured accounts. Note that Mann-Whitney $U$ tests were performed on the median values but that the results here show mean values as these have more meaning for a lending business. Appendix 3 has additional descriptive statistics for the four groupings of accounts. 
The results of Mann-Whitney $U$ tests on the mean cash flow margin of all four groups of accounts: good, default, cured and write off. The probability levels for each Mann-Whitney U test (at an error level of $5 \%$ ) revealed that the values of the different medians (and means) were statistically significant.

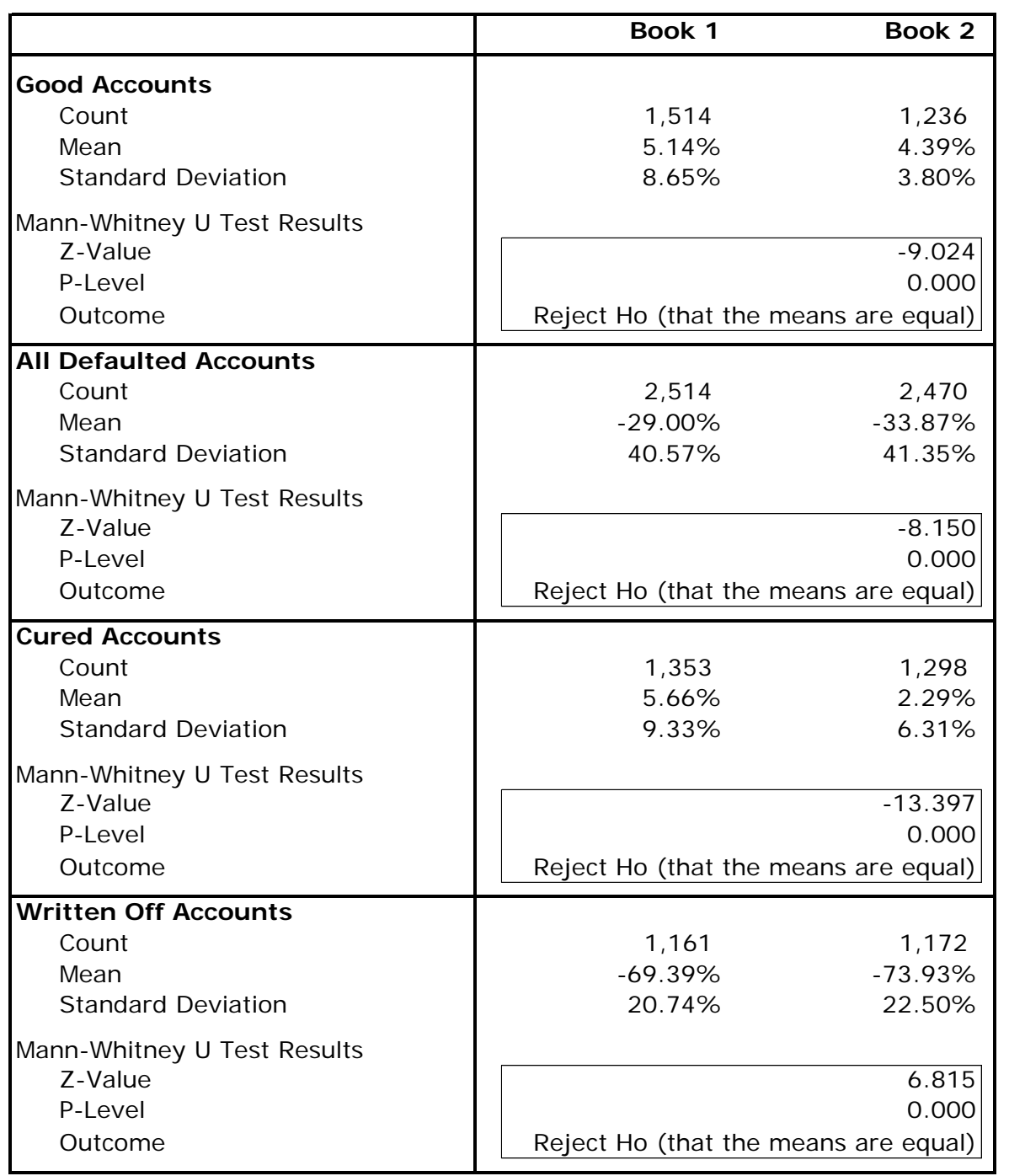

\subsubsection{Total Cash Flow Margin}

The mean cash flow margin previously described suffered from the limitation that it was unaffected by the magnitude of the different loans. Because it was a ratio, 


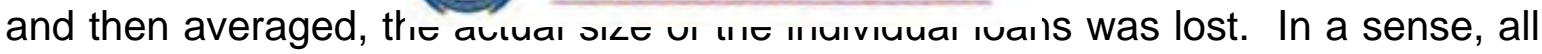
loans were equally weighted in calculating the outcome. While this was not too significant a limitation an alternative metric was also examined. The Total Cash Flow Margin (TCFM) was defined as follows:

$T C F M=\frac{\sum P V(\text { Actual_Payments })-\sum P V(\text { Expected_Payments })}{\sum P V(\text { Expected_Payments })}$

\section{Equation 6 Total Cash Flow Margin}

Table 5-4 below shows the total cash flow margin for good and defaulted loans in the two loan books using different collections strategies.

Table 5-4 Total Cash Flow Margin per Book

\begin{tabular}{|l|c|c|}
\cline { 2 - 3 } \multicolumn{1}{c|}{} & $\begin{array}{l}\text { Book1: Behaviour } \\
\text { Based Collections }\end{array}$ & $\begin{array}{l}\text { Book 2: Arrears } \\
\text { Based Collections }\end{array}$ \\
\hline $\begin{array}{l}\text { Good } \\
\text { Loans }\end{array}$ & $3.8 \%$ & $4.4 \%$ \\
\hline $\begin{array}{l}\text { Defaulted } \\
\text { Loans }\end{array}$ & $-32.9 \%$ & $-35.6 \%$ \\
\hline
\end{tabular}

The results are slightly different to those for mean cash flow margin as they are based on total values and not means, but they follow a similar pattern. 


\subsection{Collections Ohıuı!}

The eventual collections outcome, either write off or cure, was also examined, as shown in Table 5-5 below. The chi square test reveals that there is no significant deviation from the expected results.

Table 5-5 Chi Square Test of Collections Outcome vs. Collections Strategy

The number of accounts that were either written off or cured did not vary significantly with the collections strategy employed. This suggests that the eventual outcome of collections was not affected by collections strategy.

\begin{tabular}{|c|c|c|}
\hline \multirow{2}{*}{ Actual Counts } & \multicolumn{2}{|c|}{ Outcome } \\
\hline & Cure & Write Off \\
\hline $\begin{array}{l}\text { Book1: Behaviour } \\
\text { Based Collections }\end{array}$ & 1,353 & 1,161 \\
\hline $\begin{array}{l}\text { Book2: Arrears Based } \\
\text { Collections }\end{array}$ & 1,298 & 1,172 \\
\hline
\end{tabular}

\begin{tabular}{|c|c|c|}
\hline \multirow{2}{*}{ Expected Counts } & \multicolumn{2}{|c|}{ Outcome } \\
\hline & Cure & Write Off \\
\hline $\begin{array}{l}\text { Book1: Behaviour } \\
\text { Based Collections }\end{array}$ & 1,337 & 1,177 \\
\hline $\begin{array}{l}\text { Book2: Arrears Based } \\
\text { Collections }\end{array}$ & 1,314 & 1,156 \\
\hline
\end{tabular}

Chi-Square:

0.805

Probability Level:

0.370

Outcome:

Do Not Reject Ho 


\subsection{Cost to Collect}

The cost to collect was approximated by examining the number of months in which there was a right party contact (RPC) with the customer while the account was in collections.

\section{Table 5-6 Right Party Contacts (RPC) per Collections Strategy}

The mean number of contacts between the collections department and each client in default. The Mann-Whitney $U$ test results suggested that the cost to collect, approximated by number of right party contacts (RPC), was higher in Book 2 which used arrears based collections.

\begin{tabular}{|l|rr|}
\hline & Book 1 & Book 2 \\
\hline Number of RPC & & \\
Num Accounts & 2,514 & 2,470 \\
Mean RPC per Account & 3.36 & 6.83 \\
Standard Deviation & 2.34 & 4.94 \\
Minimum & 1.00 & 1.00 \\
Maximum & 18.00 & 31.00 \\
\hline Mann-Whitney U Test Results & & -27.900 \\
Z-Value & & 0.000 \\
P-Level & & \\
Outcome & Reject Ho (that the means are equal) \\
\hline
\end{tabular}

\subsection{Change in Credit Risk}

The relationship between cash flow margin and change in credit risk was also examined. Table 5-7 below shows the results of a chi square test on the number of accounts that increased or decreased in credit risk across the two loan books. The results show that there was no relationship between the increase (or decrease) in credit risk and the book in which the loan was from. 
The results of this chi square test showed that change in credit risk (and the direction of that change) were not related to book source. This further confirmed the similarity of the two samples. Note that change in credit risk was measured at the time of default and was thus not a measure of collections strategy.

\begin{tabular}{l}
\cline { 2 - 4 } \multicolumn{1}{c|}{ Actual Counts } \\
\begin{tabular}{|l|c|c|c|}
\hline $\begin{array}{l}\text { Book1: Behaviour } \\
\text { Based Collections }\end{array}$ & 558 & 1,692 & 264 \\
\hline $\begin{array}{l}\text { Book2: Arrears } \\
\text { Based Collections }\end{array}$ & 519 & 1,708 & 243 \\
\hline
\end{tabular}
\end{tabular}

\begin{tabular}{l}
\cline { 2 - 5 } Expected Counts \\
\begin{tabular}{|l|c|c|c|}
\hline $\begin{array}{l}\text { Book1: Behaviour } \\
\text { Based Collections }\end{array}$ & 543 & 1,715 & 256 \\
\hline $\begin{array}{l}\text { Book2: Arrears } \\
\text { Based Collections }\end{array}$ & 534 & 1,685 & 251 \\
\hline
\end{tabular}
\end{tabular}

Chi-Square:

1.969

Probability Level:

0.374

Outcome:

Do Not Reject Ho

The next results, in Table 5-8 and Table 5-9, show the results of chi square tests on the change of credit risk against the cash flow margin per book. This was to determine if there was a relationship between change in credit risk and change in cash flow. The results show that an increase in credit risk resulted in more accounts experiencing a decrease in cash flow margin and vice versa. 
The results of this chi square test show that there was a relationship between change in credit risk and the number of accounts that experienced a change in cash flow for the better or worse. If credit risk decreased, more accounts had increased cash flow; if credit risk increased more accounts had decreased cash flow.

\begin{tabular}{l}
\cline { 2 - 5 } \multicolumn{1}{c|}{ Actual Counts } \\
\begin{tabular}{|l|c|c|c|}
\hline $\begin{array}{l}\text { Negative Cash } \\
\text { Flow Margin }\end{array}$ & 228 & 1,071 & 161 \\
\hline $\begin{array}{l}\text { Positive Cash Flow } \\
\text { Margin }\end{array}$ & 330 & 621 & 103 \\
\hline
\end{tabular}
\end{tabular}

\begin{tabular}{|c|c|c|c|}
\hline \multirow{2}{*}{ Expected Counts } & \multicolumn{3}{|c|}{ Change in Credit Risk } \\
\hline & Decrease & ncrease & None \\
\hline $\begin{array}{l}\text { Negative Cash } \\
\text { Flow Margin } \\
\end{array}$ & 324 & 983 & 153 \\
\hline $\begin{array}{l}\text { Positive Cash Flow } \\
\text { Margin }\end{array}$ & 234 & 709 & 111 \\
\hline
\end{tabular}

Chi-Square:

87.79

Probability Level:

0.000

Outcome:

Reject Ho 
Table 5-9 Chi Square i co - vilailye ıi vicui risn vo. Jash Flow Margin (Book 2)

The results of this chi square test are very similar to those in Table 5-9, and also show that when credit risk increased, there were more accounts that had reduced cash flow (and vice versa).

\begin{tabular}{|c|c|c|c|}
\hline \multirow[t]{2}{*}{ Actual Counts } & \multicolumn{3}{|c|}{ Change in Credit Risk } \\
\hline & Decrease & Increase & None \\
\hline $\begin{array}{l}\text { Negative Cash } \\
\text { Flow Margin }\end{array}$ & 286 & 1,219 & 168 \\
\hline $\begin{array}{l}\text { Positive Cash Flow } \\
\text { Margin }\end{array}$ & 233 & 489 & 75 \\
\hline
\end{tabular}

\begin{tabular}{|c|c|c|c|}
\hline \multirow[t]{2}{*}{ Expected Counts } & \multicolumn{3}{|c|}{ Change in Credit Risk } \\
\hline & Decrease & Increase & None \\
\hline $\begin{array}{l}\text { Negative Cash } \\
\text { Flow Margin }\end{array}$ & 352 & 1,157 & 165 \\
\hline $\begin{array}{l}\text { Positive Cash Flow } \\
\text { Margin }\end{array}$ & 168 & 551 & 78 \\
\hline
\end{tabular}

Chi-Square:

48.42

Probability Level:

0.000

Outcome:

Reject Ho 


\section{Chapter 6: Discussion of Results}

This chapter discusses the results presented in Chapter 5 and provides insight into the hypotheses laid out in Chapter 3. The chapter is organised as follows: each set of hypotheses is preceded by a discussion of the results for each relevant construct. This is followed by the findings for each hypothesis. Where possible the findings are compared and contrasted to the literature in Chapter 2. In most cases this is a comparison to espoused industry best practice because, as previously mentioned, there is little literature on the subject of collections and even less on the subject of behaviour based collections.

\subsection{Cash Flow Margin}

Results for the mean cash flow margins on the different sub-populations examined are shown in Table 5-3. On average, the good loans in Book 1 had an actual cash flow 5.14\% greater than expected, while those in Book 2 had a similar result, with cash flow 4.39\% higher than expected. The standard deviation in cash flow margin for Book 1 was $8.65 \%$, while that of Book 2 was $3.80 \%$.

The fact that the mean cash flow margin for good accounts was positive, indicating that there was more revenue than expected on these loans, was due to early repayments of debt. An early repayment meant a decrease in interest income, but also caused an increase in the present value the administration fees on the loan. The spread of values in this measurement was due to the timing of the early settlements as well as different admin fees charged on the various loans.

The mean cash flow margin of accounts that were in default was significantly lower 
than that of good accuurıs. rus vuun \& ur valuc vi the mean cash flow margin was $-29.00 \%$, while for Book 2 the cash flow margin was $-33.87 \%$ (note that these results were the adjusted results, after applying the offset from the control sample). The loss was greater for accounts collected on using an arrears based strategy. This finding is in contrast to industry best practice (as described in Bailey, 2002; Rial, 2005; Ward, 2005a; Shortbridge, 2006) that suggests that arrears based collections is the best method to follow.

The standard deviation of this metric in both books was over $40 \%$, which indicated a wide distribution of results. This was due to the fact that there were two distinct outcomes for accounts in default. Accounts would either get rehabilitated at some point, or they would get written off.

In general, those accounts that were rehabilitated would yield increased cash flow as the loan term was extended and the client was charged interest on the late payments at a rate above the discount rate. Accounts that were written off tended to have significantly decreased cash flow as those accounts were not being paid at all. This resulted in the bimodal distribution of cash flow margin shown in Figure 4.

For rehabilitated accounts, a behaviour based collections strategy resulted in a cash flow margin of $5.66 \%$, while an arrears based collections strategy led to an increase in cash flow of $2.29 \%$. These results included adjustment due to the control sample, and thus represent the real increase in revenue for those accounts. The increase in revenue was greater for accounts collected on using a behaviour based collections strategy than those collected on using an arrears based collections strategy. Accounts using the former strategy tended to earn interest on 


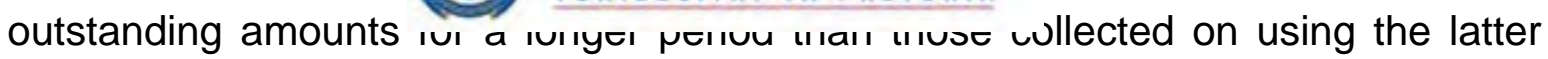
strategy. This finding suggests that behaviour based collections, used when clients cannot afford to pay their arrears, serves the interest of both the debtor and creditor. There is little evidence in the literature or industry best practice that this approach has been considered.

For written off accounts, the cash flow margin for Book 1 was $-69.39 \%$, while that from Book 2 was $-73.93 \%$. This represents significant losses on all written off accounts, but the losses on accounts collected on using behaviour based collections were $4.54 \%$ lower than those experienced on arrears based collections. This is a surprising result as industry best practice suggests that for accounts that are very delinquent attempts should be made to recover all outstanding monies immediately (Ward, 2005b). If this was the best approach then arrears based collections would be expected to have better revenues than behaviour based collections.

\subsubsection{Hypothesis 1}

Hypothesis 1 was tested, where

$$
\begin{aligned}
& \mathrm{H}_{0}: C F M_{\mathrm{BBC}}=C F M_{\mathrm{ABC}} \\
& \mathrm{H}_{\mathrm{A}}: C F M_{\mathrm{BBC}}<>C_{\mathrm{ABC}}
\end{aligned}
$$

Based on the results in Table 5-3, and the discussion in 6.1 above, the null hypothesis was rejected. The actual payments received on defaulted loans (as measured against expected payments) were greater when a behaviour based collections strategy was used. 


\subsubsection{Hypothesis $1 \mathrm{a}$}

Hypothesis 1a was tested, where

$\mathrm{H}_{0}: C F M_{\mathrm{BBC}}$ of cured loans $=C F M_{\mathrm{ABC}}$ of cured loans

$\mathrm{H}_{\mathrm{A}}:$ CFM $M_{\mathrm{BBC}}$ of cured loans $>C F M_{\mathrm{ABC}}$ of cured loans

Based on the results in Table 5-3, and the discussion in 6.1 above, the null hypothesis was rejected. The actual payments on defaulted loans that eventually cure were greater when a behaviour based collections strategy was used than when an arrears based collections strategy was used.

\subsubsection{Hypothesis $1 b$}

Hypothesis $1 b$ was tested, where

$\mathrm{H}_{0}: C F M_{\mathrm{BBC}}$ of written off loans $=C F M_{\mathrm{ABC}}$ of written off loans

$\mathrm{H}_{\mathrm{A}}: C F M_{\mathrm{BBC}}$ of written off loans $<>C F M_{\mathrm{ABC}}$ of written off loans

Based on the results in Table 5-3 and the discussion in 6.1 above, the null hypothesis was rejected. Defaulted loans that eventually get written off experienced better cash flow prior to write off when a behaviour based collections strategy was used than when an arrears based collections strategy was used.

\subsection{Collections Outcome}

A comparison was made of the number of accounts that were written off or cured in the different loan books. The results of the chi square test in Table 5-5 show that collection strategy did not have an impact on the eventual outcome. 
This is a surprising resuir as uा purpuse u cuicuuvis strategy is to reduce the likelihood of write off, and increase the number of accounts that cure (Bailey, 2002). A possible explanation is that once contact is made with a client, the collections method employed will not change the client's circumstances. In other words, if a customer is unable to pay, no collections strategy will be able to make them pay.

When this result is combined with the discussion in 6.1 that showed the positive impacts on cash flow due to a behaviour based collections strategy, it appears that it is both safe and advisable to use a behaviour based strategy. Safe, because there is no impact on the eventual outcome, and advisable because there is increased revenue.

\subsubsection{Hypothesis 2}

Hypothesis 2 was tested, where

$$
\begin{aligned}
& \mathrm{H}_{0} \text { : Collections Outcome }{ }_{B B C}=\text { Collections Outcome }{ }_{A B C} \\
& \mathrm{H}_{\mathrm{A}} \text { : Collections Outcome }{ }_{B B C}<>\text { Collections Outcome }{ }_{A B C}
\end{aligned}
$$

Based on the results in Table 5-5, and the discussion in 6.2 above, the null hypothesis was not rejected. The research found no relationship between the outcome of the collections process (whether the account is written off or cured) and the collections strategy employed.

\subsection{Cost to Collect}

The cost to collect was examined by measuring the number of months in which 
contact was made Wıи uı vıсı vvıис uг aucuuı was in collections. These results are shown in Table 5-6. On average, accounts in Book 1 were contacted 3.36 times while accounts in Book 2 were contacted 6.83 times while they were in collections. The cost to collect was lower for behaviour based collections. This could be due to the fact that those accounts were in collections for a shorter period of time, or because fewer accounts that were rehabilitated defaulted again, or because the accounts that started paying were treated as a lower priority and not called. (This research was not designed to identify the reason for the difference in costs so this would have to be clarified by future research.)

This result further strengthens the case for behaviour based collections. It suggests that more cash will be received at a lower cost without increasing the likelihood of write off.

\subsubsection{Hypothesis 3}

Hypothesis 3 was tested, where

$$
\begin{aligned}
& H_{0}: \text { Cost }_{B B C}=\text { Cost }_{A B C} \\
& H_{A}: \text { Cost }_{B B C}<>\text { Cost }_{A B C}
\end{aligned}
$$

Based on the results in Table 5-6, and the discussion in 6.3 above, the null hypothesis was rejected. The cost to collect using behaviour based collections is significantly lower than the cost to collect using arrears based collections.

\subsection{Change in Credit Risk}

The research also investigated the impact that changes in credit risk, as defined in 


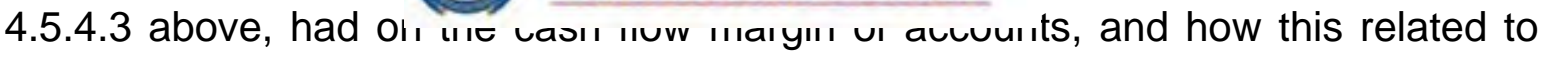
collections strategy. The first set of analysis aimed to establish if there was an inherent difference in the quality of the loans in the samples from the two different loan books. Table 5-7 shows the results of a chi square test on change in credit risk against loan book. The test indicated that there was no difference in the number of accounts that either increased or decreased in credit risk due to the business at which the loan was booked.

The next test established if there was a relationship between the change in credit risk and the cash flow margin. The results for a chi square test of are shown in Table 5-8 for Book 1 and Table 5-9 for Book 2. Both tests indicated that there is a relationship between change in credit risk and cash flow margin. In both cases, when the credit risk decreased, there were more accounts with increased cash flow margins than expected. When the credit risk increased, there were more accounts with decreased cash flows than expected. This is not surprising, and it suggests that when the credit risk of a client increases, the actual revenue received is likely to decrease.

\subsubsection{Hypothesis 4}

Hypothesis 4 was tested, where

$\mathrm{H}_{0}$ : $C F M_{\mathrm{BBC}}$ does not vary in accordance with change in risk between loan grant date and default date.

$\mathrm{H}_{\mathrm{A}}$ : $C F M_{\mathrm{BBC}}$ varies in accordance with change in risk between loan grant date and default date. 


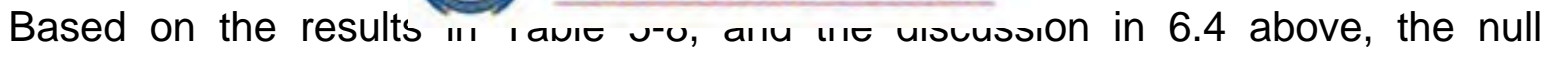
hypothesis was rejected. There is an inverse relationship between change in credit risk and change in cash flow for accounts collected on using a behaviour based collections strategy.

\subsubsection{Hypothesis 4a}

Hypothesis 4a was tested, where

$\mathrm{H}_{0}$ : CFM $M_{\mathrm{ABC}}$ does not vary in accordance with change in credit risk between loan grant date and default date.

$\mathrm{H}_{\mathrm{A}}$ : $C F M_{\mathrm{ABC}}$ varies in accordance with change in credit risk between loan grant date and default date.

Based on the results in Table 5-8, and the discussion in 6.4 above, the null hypothesis was rejected. There is an inverse relationship between change in credit risk and change in cash flow for accounts collected on using an arrears based collections strategy. 


\section{Chapter 7: Conclusion}

This research aimed to examine the impact that collections strategy had on microloan profitability. Two strategies were compared. The first, called arrears based collections, was the traditional method applied to collections and focused on curing accounts as fast as possible by pressurising clients to repay their missed instalments immediately. The second strategy, referred to as behaviour based collections, focused on rehabilitating the clients payment behaviour by pressurising the client to pay his next instalment and only catch up if he was in a position to do So.

Two loan books from a large bank were compared, one from a business unit that used an arrears based strategy and another from a business that used a behaviour based strategy. Metrics around payments received, eventual collections outcome, costs and the impact that a change in credit risk had on cash flow were compared across the two loan books using Mann-Whitney $U$ tests and chi-square tests.

In terms of the eventual outcome of the collections function, be it full rehabilitation of the account or debt write-off, the research found no differences due to collections strategy employed. Both arrears based collections and behaviour based collections had the same cure and write off rates.

Both collections strategies exhibited similar relationships between actual revenue and changes in credit risk. When credit risk increased between time of granting the loan and the time of default, more accounts showed a decrease in revenue than when the credit risk decreased. 


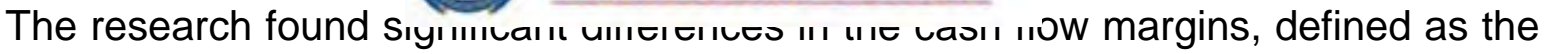
margin of revenue received to revenue expected, across the different collections strategies. In all cases, the mean cash flow margin for behaviour based collections was greater than the mean cash flow margin for arrears based collections.

For accounts that eventually cured, the cash flow margin was positive regardless of collections strategy, but accounts subjected to a behaviour based collections strategy had a mean cash flow margin of $5.66 \%$ while arrears based collections resulted in a mean cash flow margin of $2.29 \%$. Accounts collected on using a behaviour based strategy earned $3.37 \%$ more income than accounts collected on using an arrears based strategy.

Accounts that were written off despite collections attempts showed significant losses, though these were more pronounced for the book using an arrears based collections strategy. The loans that were collected on using behaviour based collections had a mean cash flow margin of $-69.39 \%$, while those collected on using an arrears based strategy had a mean cash flow margin of $-73.93 \%$, a difference of $4.54 \%$. This was a surprising result and firmly contradicts collections best practice, where the approach taken with highly delinquent accounts is to recover as much of the capital outstanding as soon as possible (Ward, 2005b). It is speculated that clients who were asked to make a payment were more likely to do so if they agreed to a smaller amount than if they were pressurised into agreeing to make a bigger payment, though this would need to be clarified in future research.

Analysis of the costs of the different strategies was done by comparing the mean 


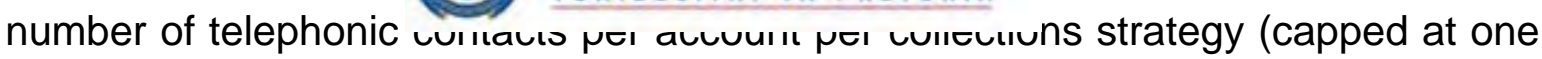
contact per month). The arrears based collections accounts were contacted, on average, 6.83 times. The behaviour based collections accounts were contacted less than half as many times, at an average of 3.36. This represents a significant saving over an arrears based strategy. Note that as the metric used (number of months in which there was a right party contact) was a proxy for costs, the exact costs savings cannot be ascertained.

The above findings strongly favour the use of behaviour based collections, but given the limitations detailed in section 4.7 , it is not advisable to assume that this strategy is categorically more profitable than arrears based collections. There are two limitations in particular that deserve more attention. Firstly, it is not possible to be certain that no operational artefacts are present in the data. Despite matching the two samples for risk characteristics, there may still be operational differences that effect the data. The second concern is that the research does not include the cost to provision for write offs. As Basle II mandates that all loans with an arrears of 90 days or more be classified as bad or doubtful debt (Pearson \& Greef, 2006), provisioning methodologies tend to be based on arrears statuses. Behaviour based collections does not focus on arrears directly so the book may appear worse than it is, and this has an opportunity cost associated with it.

Despite the above limitations, the research remains valid. The lack of academic literature on collections strategy means that any research in this area is beneficial. The situation does, however, suggest a need for additional research in this field. The following areas deserve additional study: 
- Research into uı ııaıı cusı uııeıs uıa ale aııected by collections strategy, with particular reference to the length of time an account spends in collections as well as the number of times an account re-enters collections.

- Research to establish if there is a benefit to the client in using a behaviour based strategy. In particular the finding that behaviour based collections led to better revenue for written off account should be understood from a payment behaviour perspective.

- Research into provisioning methodologies to see if they can be adapted to this form of collections strategy. In particular to understand if two accounts with the same arrears status but different payment behaviours should be provisioned for at different levels, and if this has a material impact on the total provisioning level of a business.

The most substantial contribution of this study is that it is one of the few, if not the only, studies that examine the impact that a collections strategy tailored for the circumstances of low income earners has on the actual profitability of defaulted microloans. The study finds that current collections best practice should be reexamined in the light of a behaviour based strategy that delivers superior results.

In closing, this study lends itself to the following recommendations:

- Collections departments should investigate the use of behaviour based collections. The most appropriate way to do this is through a "test and learn" approach. Measurements of the success rate of the strategy must be aligned with the strategy itself, so must include payments received over a period of time, and not just the arrears status of the loan book. 
- Where behaviour naseu cuirecuvis is useu, piuvisıoning methodologies should be adapted to include the outcomes of behaviour based collections. Good clients who pay regularly but are in arrears are more profitable than up to date good clients. It is ill advised to provide for those clients at the same level as non-performing arrears accounts.

- Until provisioning methods are adapted, businesses using behaviour based collections should collect on arrears once the client has shown more consistent payment behaviour. This can be done in a low cost, soft manner.

Behaviour based collections presents an opportunity for a win-win situation for both a bank and it's low income clients in financial distress. Allowing a delay in the repayment of arrears makes the collections method less susceptible to events in the client's life that impact on her ability to pay in the short term. The over-indebted client is granted an opportunity to recover from their financial situation. In return, the bank enjoys increased income at a lower cost. 


\section{REFERENCES}

African Bank Trading Update (2006) Trading Update for the Third Quarter Ending

30 June 2006. Available from

http://www.africanbank.co.za/financials/q32006/ABIL 3Quarter update2006.pdf.

(Accessed on 31 July 2006.)

Bailey, M. (2002) The Importance and Role of Collections. In Bailey, M. (ed.) Consumer Collections \& Recoveries: Operations and Strategies. Bristol: White Box Publishing.

Barron, J. \& Staten, M. (2000) The Value of Comprehensive Credit Reports: Lessons from the U.S. Experience, Credit Research Center, McDonough School Business, Georgetown University.

Bloomberg (2006) Credit Growth Accelerates at Record Pace. Business Report, May 5. Available from http://www.busrep.co.za/index.php?fArticleld=3233104. (Accessed on 28 August 2006.)

Bollapragada, S. \& Nair, S. (2001) Improving Right Party Contact Rates at Outbound Call Centres. GE Research \& Development Centre, Technical Information Series.

BusinessWeek (2006) Cap One's Credit Trap. BusinessWeek, November 6. Available from www.businessweek.com/magazine/content/06 45/b4008048.htm. (Accessed on 7 November 2006.)

Carling, K., Jacobson, T. \& Roszbach, K. (2001) Dormancy Risk and Expected 
Profits of Consumer Luaıı. vuuııı vi vaıııı с гııаıе, 25, 717-739.

Chandler, G. \& Johnson, R. (1992) The Benefit to Consumers from Generic Scoring Models Based on Credit Reports. Journal of Management Mathematics, $4(1), 61-72$.

Cresswell, J. W. (1994) Research Design. Qualitative and Quantitative Approaches. London: Sage.

Coetzee, G., Druschel, K., Cook, L., Brislin, N., Meagher, J. \& Pearson, R. (2005). The Evolution of the South African Microfinance Sector from 1992 to 2004: The Role of the Microfinance Regulatory Council. Ebony Consulting International Africa.

Daniels, R. (2001a) Consumer Indebtedness Among Urban South African Households: A Descriptive Overview. Working Paper 01/55. Cape Town: Development Policy Research Unit, University of Cape Town.

Daniels, R. (2001b) Financial Intermediation and The Micro-Finance Sector. Paper Presented At The TIPS 2001 Annual Forum. Cape Town: Development Policy Research Unit, University of Cape Town.

Daniels, R. (2004) Financial Intermediation, Regulation and the Formal Microcredit Sector in South Africa, Development Southern Africa, 21(5), 831-849.

DeVaney, S. A. \& Lytton, R. H. (1995) Household Insolvency: A Review of Household Debt Repayment, Delinquency, and Bankruptcy. Financial Services Review, 4(2), 137-156. 


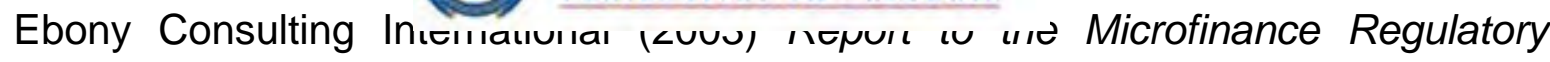

Council on the Analysis of the Application of Borrowed Funds. Available from: http://www.mfrc.co.za/files/mfrc analysis of borrowed funds.doc. (Accessed on 11 August 2006.)

FinScope (2005) FinMark Trust Banking Survey. Available from http://www.finscope.co.za. (Accessed on 31 May 2006.)

Gilmour, C. (2006) Clicks Joins Card Clique. Financial Mail. 6 October 2006.

Gunnion, S. (2006) Capitec Aims for Some Serious Bulk in Banking Mass Market. Business Day. 31 March 2006.

Hawkins, P. (2003) The Cost, Volume and Allocation of Consumer Credit in South Africa. Report published by the Department of Trade and Industry.

Hintze, J. (2005) PASS 2005 User's Guide. Utah: NCSS.

Jacobson, T. \& Roszbach, K. (2003) Bank Lending Policy, Credit Scoring and Value-At-Risk. Journal of Banking \& Finance, 27, 615-633.

Jara, M. (2005) SACP Calls for Credit Blacklisting Amnesty for All. SACP, 18 April. Available from

http://www.sacp.org.za/index.php?option=com content\&task=view\&id=225\&Itemid =127. (Accessed on 31 May 2006.)

Kim, Y. H. \& Atkins, J. C. (1978) Evaluating Investments in Accounts Receivable: A Wealth Maximizing Framework. Journal of Finance, 33(2), 403-412.

Koch, T. W. \& MacDonald, S. S. (2003). Bank Management. $5^{\text {th }}$ Edition. Ohio: 
South-Western.

Lane, S. (1972) Submarginal Credit Risk Classification. Journal of Financial and Quantitative Analysis, 7(1), 1379-1385

Marsh, D. \& Saran, N. (1999). Access to Credit for the Poor: The Borrower's Perspective. Knysna: Black Sash Trust.

Microfinance Regulatory Council (2006) Microlending Still Brisk. Quarterly Statistics 15 May 2006. Available from http://www.mfrc.co.za/detail.php?s=91. (Accessed on 31 May 2006)

Miller, R. (2002) Attitudes towards Debt Collection. In Bailey, M. (ed.) Consumer Collections \& Recoveries: Operations and Strategies. Bristol: White Box Publishing

Munshi, R. (2005) Food Before Micro Enterprise. Financial Mail, December 23, 28.

National Credit Act (2005). Act No. 34 of 2005.

Pearson, R. \& Greef, M. (2006) Causes of Default Among Housing Micro Loan Clients. FinMark Trust.

PIC Solutions (2006) Sub-Prime Lending Principles and Practices. Available from http://www.picsolutions.com/research view.asp?showid=3\&recid=272. (Accessed on 11 August 2006.)

Planting, S. (2004) The Wonderful World of Money. Financial Mail. 05 November. Available from http://free.financialmail.co.za/innovations/5nov/binn.htm. (Accessed 
on 30 May 2006.)

Porteous, D. (2003). The Landscape of Access to Financial Services in South Africa. In Lehutso-Phooko, M. (ed.) South African Reserve Bank. Labour Markets and Social Frontiers, 3, 1-6.

Repullo R. \& Suarez, J. (2004) Loan Pricing Under Basel Capital Requirements. Journal of Financial Intermediation, 13, 496-521

Rial, R. (2005) Best Practice in Consumer Collections. London: VRL Publishing Rosenberg, E.\& Gleit, A. (1994) Quantitative Methods in Credit Management: A Survey. Operations Research, 42(4), 589-513

Roszbach, K. (2004) Bank Lending Policy, Credit Scoring, and the Survival of Loans. The Review of Economics and Statistics, 86(4), 946-958.

Rust, K. (2002) Competition or Cooperation? Understanding the Relationship Between Banks and Alternative Lenders in the Low-Income Housing Finance Sector. Housing Finance Resource Programme, May 2002

Rutherford, S. (2000) Raising the Curtain on the "Microfinancial Services Era". The Consultative Group to Assist the Poorest (CGAP) Focus Series. 15. Available from www.cgap.org. (Accessed on 03 August 2006.)

Seria, N. (2006) South Africans Tighten Their Belts and Borrow Less. Business Report, June 30, Available from http://www.busrep.co.za/index.php?fArticleld=3318163. (Accessed on 28 August 2006.) 


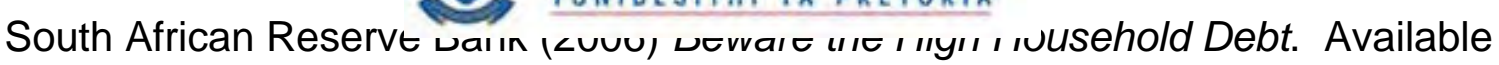

from:http://www.southafrica.info/doing business/businesstoday/economy update/

289665.htm. (Accessed on 20 May 2006.)

Schoombee, A. (2004) South African Banks and the Unbanked: Progress and Prospects. South African Journal of Economics. 72(3), 581-603.

Shortbridge, P. (2006) The Importance of Alignment Between Business and Systems Architecture in Debt Collection. Available from http://www.picsolutions.com/research view.asp?showid=3\&recid=282. (Accessed on 11 August 2006.)

Spinks, N. \& Wells, B. (1997) Collection Communications: A Problem Child of Management. Management Decision. 35(2), 106-109.

Stirling, M. (2000) Customer Value Management. Journal of Targeting, Measurement and Analysis for Marketing, 9(2), 174-184.

Sutton, R. (1991) Maintaining Norms about Expressed Emotions: The Case of Bill Collectors. Administrative Science Quarterly, 36, 245-268.

Thomas, L. C. (2000) A Survey of Credit and Behavioural Scoring: Forecasting Financial Risk of Lending to Consumers. International Journal of Forecasting, 16, 149-172.

Valentine, L. (1999) Risk-Based Pricing - On the Way? ABA Banking Journal, $91(5), 54-7$

Waggoner, D (2006) Debt Buyers in the Public Eye. Credit \& Collections World 


\section{Special Report.}

bin/readstory2.pl?story=20040601CCRU262.xml. (Accessed on 12 October 2006.)

Ward, S. (2005a) Where Are the Opportunities to Optimise Collection Performance? Credit Risk International, December-January.

Ward, S. (2005b) The Strategic Approach to Collections. Experian-Scorex, white paper.

Welman, J. C. \& Kruger, S. J. (2003) Research Methodology. $2^{\text {nd }}$ Edition. Cape Town: Oxford University Press Southern Africa

Wilson, N., Summers, B. \& Hope, R. (2000) Using Payment Behaviour for Credit Risk Modelling. International Journal of the Economics of Business, 7(3), 333-346. 


\section{Appendix}

\section{Appendix 1: Credit Bureau Scores}

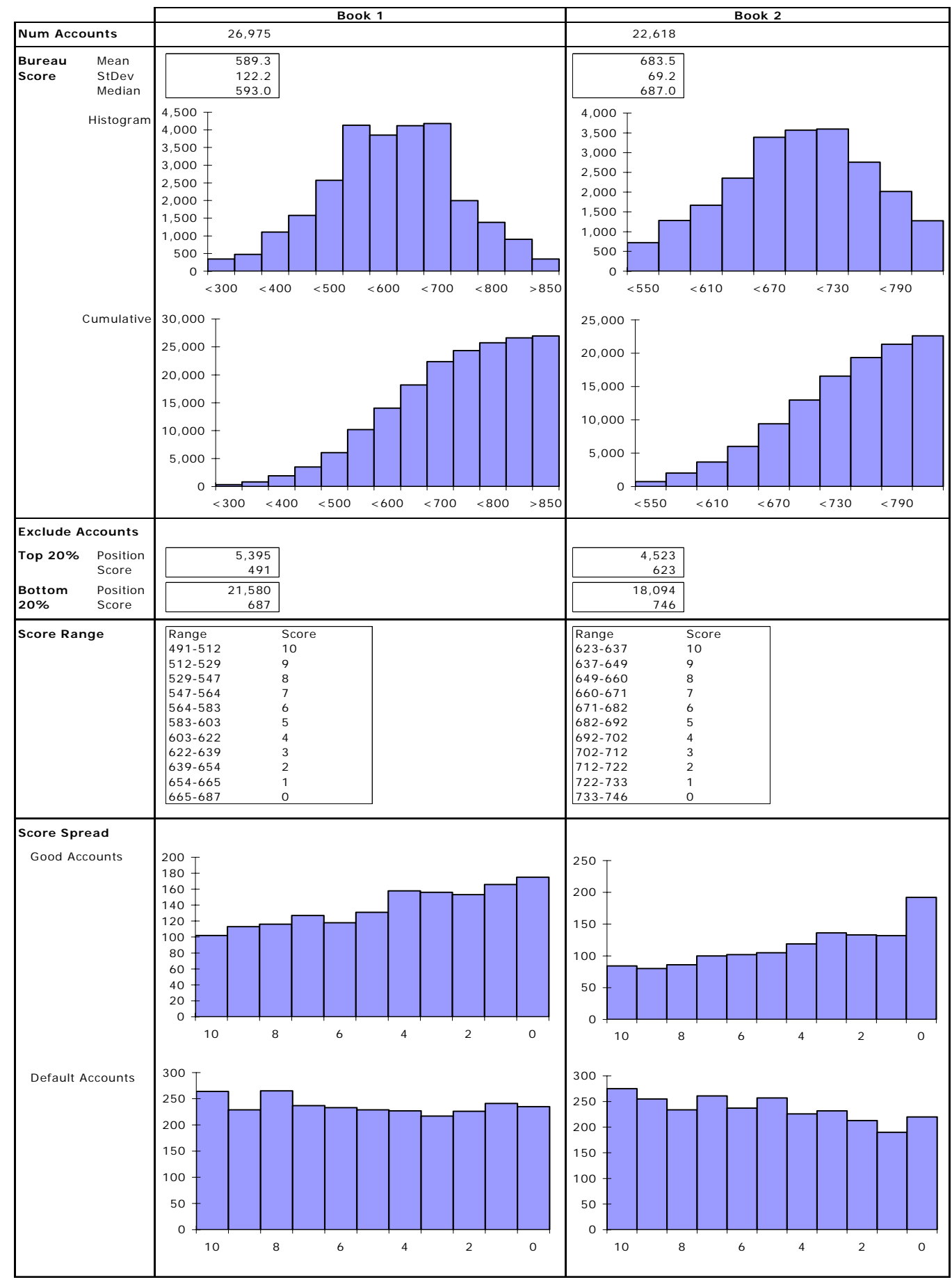

Note that the ranges are different for each book as the application scores come from different credit bureaus. 


\section{Figure 5 Histogram of Good Accounts}

Book 1

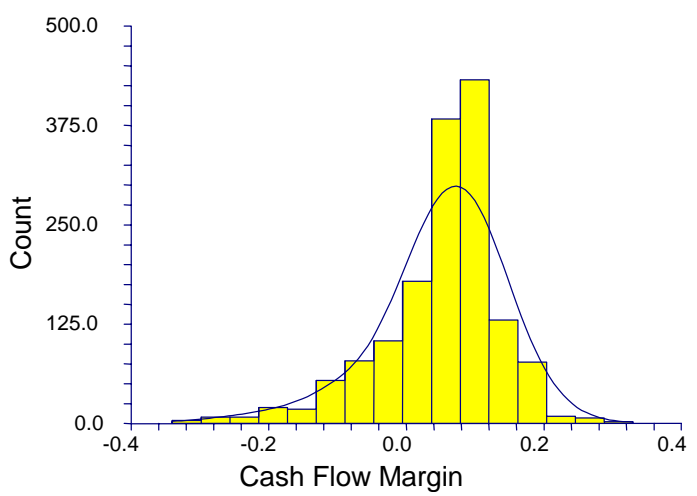

Book 2

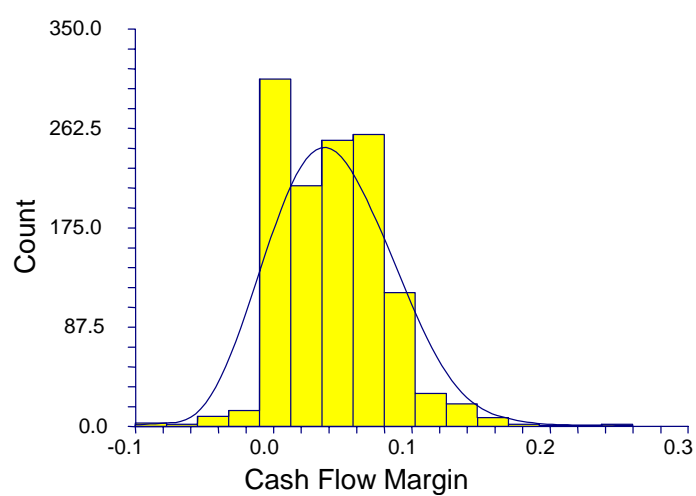

Figure 6 Histogram of Cured Accounts
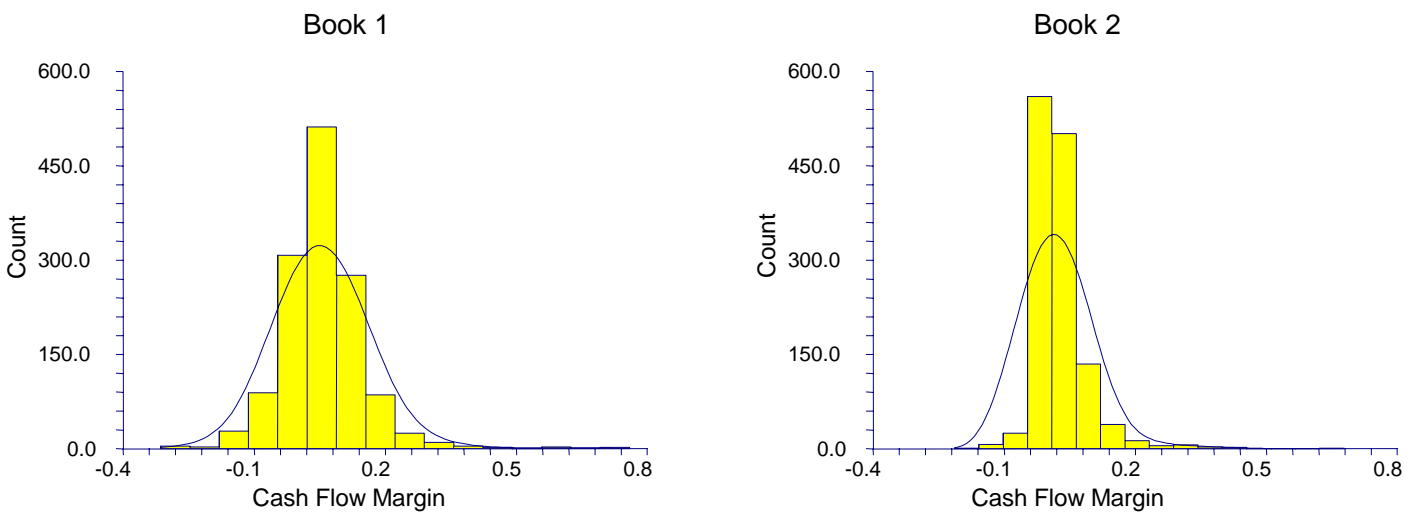


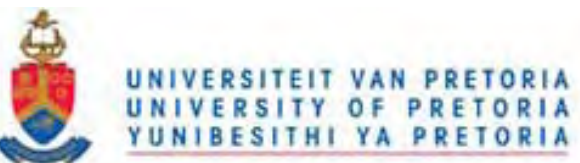

Flyuic, ilsovyıalı vi vvırucı vil micounts
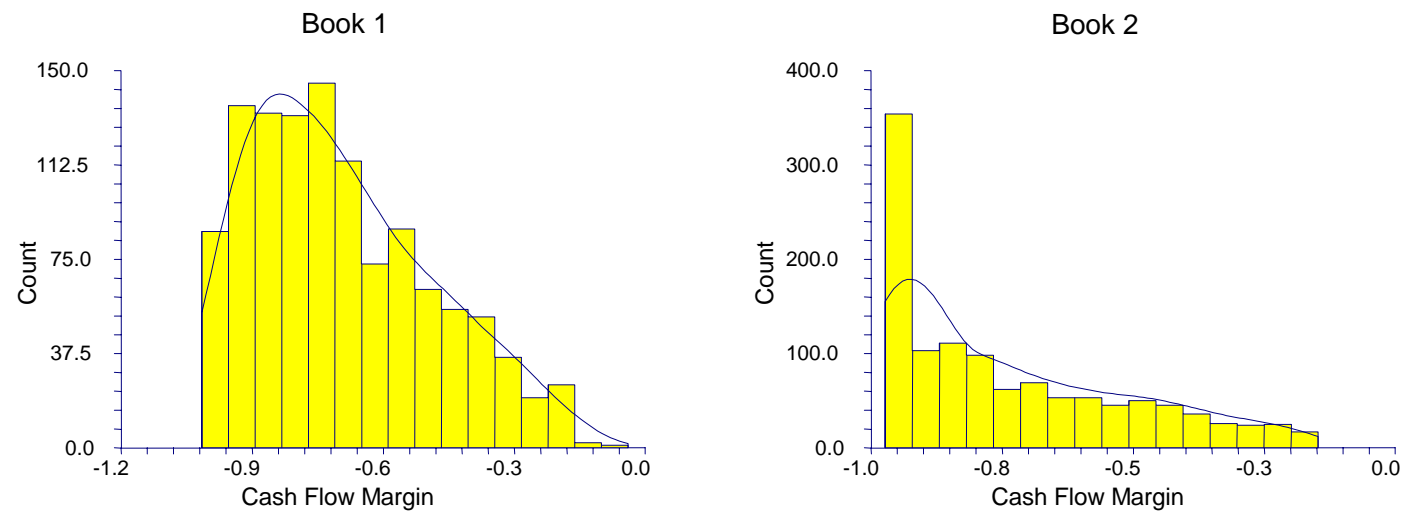


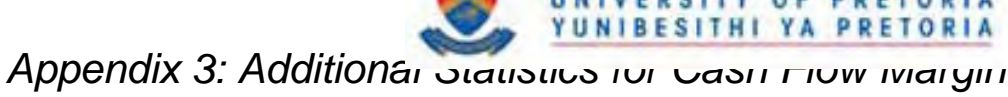

\begin{tabular}{|c|c|c|}
\hline & Book 1 & Book 2 \\
\hline \multicolumn{3}{|l|}{ Good Accounts } \\
\hline Count & 1,514 & 1,236 \\
\hline Mean & $5.14 \%$ & $4.39 \%$ \\
\hline Standard Deviation & $8.65 \%$ & $3.80 \%$ \\
\hline Standard Error & $0.22 \%$ & $0.11 \%$ \\
\hline Minimum & $-34.00 \%$ & $-10.00 \%$ \\
\hline Maximum & $33.00 \%$ & $26.00 \%$ \\
\hline \multicolumn{3}{|l|}{ All Defaulted Accounts } \\
\hline Count & 2,514 & 2,470 \\
\hline Mean & $-29.00 \%$ & $-33.87 \%$ \\
\hline Standard Deviation & $40.57 \%$ & $41.35 \%$ \\
\hline Standard Error & $0.81 \%$ & $0.83 \%$ \\
\hline Minimum & $-101.53 \%$ & $-97.29 \%$ \\
\hline Maximum & $75.97 \%$ & $67.83 \%$ \\
\hline \multicolumn{3}{|l|}{ Cured Accounts } \\
\hline Count & 1,353 & 1,298 \\
\hline Mean & $5.66 \%$ & $2.29 \%$ \\
\hline Standard Deviation & $9.33 \%$ & $6.31 \%$ \\
\hline Standard Error & $0.25 \%$ & $0.18 \%$ \\
\hline Minimum & $-31.43 \%$ & $-21.36 \%$ \\
\hline Maximum & $75.97 \%$ & $67.83 \%$ \\
\hline \multicolumn{3}{|l|}{ Written Off Accounts } \\
\hline Count & 1,161 & 1,172 \\
\hline Mean & $-69.39 \%$ & $-73.93 \%$ \\
\hline Standard Deviation & $20.74 \%$ & $22.50 \%$ \\
\hline Standard Error & $0.61 \%$ & $0.66 \%$ \\
\hline Minimum & $-101.53 \%$ & $-97.29 \%$ \\
\hline Maximum & $-3.91 \%$ & $-14.66 \%$ \\
\hline \multicolumn{3}{|l|}{ Correlations } \\
\hline Cured vs. Cash Flow Margin & 0.863 & 0.865 \\
\hline
\end{tabular}

